\title{
Variation and Optionality in Clitic Climbing in Argentinean Spanish
}

\author{
Ioanna Sitaridou \\ Queens' College, University of Cambridge \\ is269@cam.ac.uk
}

\section{Helen Whimpanny \\ University of Cambridge \\ hrw36@cam.ac.uk}

\section{Laura Ayres}

University of Cambridge

lja33@cam.ac.uk

Received: 30-04-2015

Accepted: 01-09-2015

\begin{abstract}
Since Cinque's (2006:31-32) four-way typology of languages in terms of clitic climbing (CC, herein), those in which CC displays optionality, such as Argentinean Spanish (ArgSp, herein), remain poorly understood. This paper aims to address this need. Here, we show that: (i) empirically, $\mathrm{CC}$ has remained a prevalent option in spoken ArgSp since its incipient stage (Davies 1995), yet at the same time we reveal significant diatopic variation in terms of optionality; (ii) theoretically, we capture this optionality partly in terms of 'parametric hierarchies' (Biberauer \& Roberts 2012) with no considerable impact otherwise on any macro/meso-parameter in this variety. However, in order to fully explain our data, we postulate that the macro-parameter setting makes a Pool of Variants (in the spirit of Adger (2013) and Adger \& Smith (2007)) available, in which there are options for $\mathrm{CC}$ spell out: proclisis on the matrix or enclisis on the embedded verb(s). Crucially these options do not yield interpretive effects and, therefore, the drive behind the clitic position is lexical. The probability with which one of the clitic spell out positions is selected is claimed to depend at least in part on frequency, behind which we expect a variety of sociolinguistic factors.
\end{abstract}

Keywords: clitic climbing; Argentinean Spanish; optionality; isogloss; Parametric Theory; pool of variants. 


\section{Table of Contents}

\author{
1. Introduction \\ 2. Previous Studies of Clitic \\ Climbing \\ 3. Data Collection in Argentinean \\ Spanish \\ 4. Discussion of Empirical Results \\ from the Perspective of Internal \\ Triggers
}

\author{
5. Clitic Climbing as an Emerging \\ Isogloss in ArgSP \\ 6. On Clitic Climbing "True" \\ Optionality \\ 7. Capturing the optionality of $\mathrm{CC}$ in \\ the grammar of Spanish \\ 8. Conclusions \\ 9. References
}

\section{Introduction}

The goal of this paper is twofold: (i) empirically, to discuss variation in clitic climbing (hereafter CC) in different varieties of Argentinean Spanish (hereafter ArgSp) and exhaustively assess it against an extremely comprehensive list of variables identified to be linked to $\mathrm{CC}$, both formal and functional, language internal and external; and (ii) theoretically, to contribute to the understanding of optionality in $\mathrm{CC}$ in close cognates in terms of parametric syntax. The major contribution of this paper is how (i) certain seemingly purely syntactic phenomena can only be explained by taking recourse to various linguistic variables rather than syntactic parameters alone; (ii) the data one finds in the field contradict what has been found in the literature; (iii) one can account for optionality in the grammar.

$\mathrm{CC}$ is considered to be a hallmark of restructuring (or "clause union" phenomena). It consists of a, at times seemingly optional, syntactic process whereby "a clitic, syntactically dependent on the lower $\mathrm{V}$, and thus attached to the lower V, can be attached to the upper V" (Rivas, 1977: 120); "Clitics skip over non-finite complement verbs with null subjects, apparently optionally, and attach to a closed subset of higher governing verbs. These verbs in Italian and Spanish are called 'restructuring verbs' after the classic study of Rizzi (1978)" (Emonds, 1999: 291).

Since Cinque (2006:31-32), a typology of languages with regard to CC consists of:

(a) languages in which $\mathrm{CC}$ is mostly optional (e.g., Spanish, European Portuguese);

(b) languages with pervasive and obligatory CC (e.g., many central Italian varieties, Sardinian);

(c) languages with little or no CC (e.g., French, Romanian and Brazilian Portuguese);

(d) languages with clitics which surface in several positions (e.g., Chilean Spanish, Neapolitan, certain Piedmontese varieties).

Although type (b) languages have attracted many analyses (Cardinaletti \& Shlonsky 2004, inter alios) and type (c) languages receive the explanation that either the null subject property has been relaxed (i.e., Brazilian Portuguese) (Cyrino 2009, 2010b, inter alios) or lost entirely (i.e., French) (Rochette 1988, Martineau 1990, Kayne 1989), or that infinitives are on the decline (i.e., Romanian) (Monachesi 1998), type (d) and type (a) languages are less wellunderstood. Consider Peninsular Spanish (SPSp) -a typical type (a) language- 
which has optional $\mathrm{CC}$, as shown in (1):

a. Debo hacerlo must.1SG do.INF-CL.DO.3SG.MAS

$[-\mathrm{CC}]$

(SPSp) 'I must do it'

b. Lo debo hacer $[+\mathrm{CC}]$ CL.DO.3SG.MAS must.1SG do.INF 'I must do it'

c. Solía visitarme used-to.3SG visit.INF-CL.DO.1SG

$[-\mathrm{CC}]$

(SPSp) 'He used to visit me'
d. $\mathrm{Me}$ solía visitar
$[+\mathrm{CC}]$

CL.DO.1SG used-to.3SG visit.INF

'He used to visit me'

(Bosque et al 2009: 1234)

The same pattern of optional CC seems to obtain in ArgSp, at least superficially:
a. Entonces, vamos a averiguarlo.
$[-\mathrm{CC}]$ then go.1PL to find-out.INFIN-CL.DO.3SG.MAS
(ArgSp/SPSp)
'So, we're going to find out about it.'
b. Entonces, lo vamos a then CL.DO.3SG.MAS go-1PL to averiguar. find-out-INFIN
$[+\mathrm{CC}] \quad(\mathrm{ArgSp} / \mathrm{SPSp})$
'So, we're going to find out about it.'

The ArgSp data in (2) seem to confirm that CC, when it is allowed, is an apparently optional syntactic process, like the one observed for SPSp. However, a more careful examination reveals that the optionality is not of the same kind since (3) is possible in both SPSp and ArgSp, whereas (4) is not possible in SPSp, but is possible in ArgSp:

(3) Seguramente, necesitarán lavarse los dientes Surely need.FUT.3PL wash.INFIN-CL.PASS.3PL the teeth 'They are sure to need their teeth cleaning'

(ArgSp/SPSp)
Seguramente, se
necesitarán lavar los dientes. surely
CL.PASS.3PL need.FUT.3PL wash.INFIN the teeth
'They are sure to need their teeth cleaning'
(ArgSp/*SPSp)

In general, necesitar, 'need to', does not allow CC in SPSp, but, as will be shown in section 4, this matrix verb returned positive results for CC in ArgSp. This is not to say that ArgSp categorically opts for CC in complex predicates headed by necesitar, 'need to', but rather that it is an option. What exactly is it about ArgSp that means that both enclisis and proclisis in complex verb phrases 
are possible in ArgSp? Is it just the properties of the matrix verb, necesitar, 'need to', that are responsible for where clitics surface here? ${ }^{1}$

In this article we focus on ArgSp and we show that CC-acceptability data, from a number of ArgSp varieties tested here, exhibit wide-ranging optionality with regards to $\mathrm{CC}$. In particular: (i) empirically, we show that $\mathrm{CC}$ has remained a prevalent option in spoken ArgSp since its incipient stage, colluding with Davies (1995), yet at the same time here we reveal significant diatopic variation in terms of optionality; (ii) theoretically, we capture this optionality in terms of 'parametric hierarchies' (in the sense of Biberauer \& Roberts 2012) with no considerable impact otherwise on the macro/meso-parameter regulating $\mathrm{CC}$ in this variety. Importantly, however, this model does not fully explain our data. We postulate that the macro-parameter setting makes a Pool of Variants (in the spirit of Adger (2013) and Adger \& Smith (2007)) available, in which there are two options for CC spell out whenever there is one matrix and one embedded verb: proclisis on the matrix or enclisis on the embedded (with more matrix verbs we would have more variants). Crucially these (most commonly two) options do not yield interpretive effects and, therefore, the drive behind the clitic position in these instances is lexical in nature. The probability with which one of the clitic spell out positions is selected is claimed to depend at least in part on frequency, behind which we find a variety of sociolinguistic factors. It is suggested that, over time, frequent selections could result in a nano-parameter setting, but this is impossible to prove either way due to methodological constrictions.

The remainder of the article comprises as follows: section 2 offers a survey of CC triggers as described in the existing literature. In section 3 , the methodology is discussed. In section 4, the empirical results are reported and analysed so as to assess the level of influence that internal triggers hold over CC in ArgSp. Section 5 presents the reader with an emerging isogloss that can be drawn to map out the variation encountered in ArgSp. Section 6 discusses 'true' optionality data while section 7 offers an explanation for how we can conceptualise this attested optionality. Finally, we conclude in section 8 .

\section{Previous Studies of Clitic Climbing}

The appearance of pronominal clitics and their various positions in Romance varieties could be argued to be one of the most striking developments of these languages from their initial state Latin. Moreover, CC in these type (a) languages has been gaining a growing amount of attention in the literature, their inherent optionality being especially of interest. Varying authors have investigated both

$1 \quad$ One of the reviewers pointed out that the difference in clitic positions in (3) and (4) could be due to potentially different meanings that the se clitic receives. An educated speaker (who was not an informant for the main study) analysed the se clitic in (3) / (4) here as reflexive without any context. However, the structure was taken from a news piece on hippopotamuses in a magazine by a high-profile journalism and media group in Argentina. Therefore, given this context, here I analysed the clitic as passive se. Once the context was provided to the native speaker, he did not find any difference in the meaning of the se clitic, just a preference for (3). 
formal and functional accounts with respect to these optional clitic positions. In this section we discuss the language-internal and -external variables which have been claimed to be at work with regards to the trigger of CC.

\subsection{Language-Internal Variables and Clitic Climbing}

\subsubsection{Semantics of Matrix Verb}

The most important variable affecting $\mathrm{CC}$ identified in the literature is the semantic properties of the matrix verb governing the non-finite complement in which clitics are generated (Myhill 1988, 1989, Davies 1995, Napoli 1981, Rizzi 1976, 1982, Aissen \& Perlmutter 1983, inter alios). Formal and functional accounts, however, differ in their approaches to classifications of the matrix.

First we turn our attention to formal accounts of CC which centre on the syntactic notion of Restructuring (Rizzi, 1976: 2). According to Rizzi (1982: 2) verbs which can undergo $\mathrm{CC}$ are subject to an optional rule which converts "an underlying bisentential structure into a simple sentence, creating a unique verbal complex consisting of the main and the embedded verb". Aissen \& Perlmutter (1983: 360, henceforth A\&P) characterise this as "a rule of Clause Reduction that makes dependents of a complement verb dependents of the matrix verb", whereupon any matrix sensitive to the rule may optionally host those clitics which are dependent on the embedded non-finite verb. Both accounts claim that membership to a group is binary; a given matrix either categorically affords Restructuring or does not. Rizzi (1982) and A\&P (1983) therefore label matrices as (non)Restructuring and (non)Trigger verbs respectively. Rizzi (1982: 41), however, notes that matrices are assigned to these roles on an idiolectal basis in that "...judgments vary from speaker to speaker even in determining the welldefined classes", which is also echoed by A\&P (1983: 363). Interestingly, this statement about the optionality surrounding restructuring verbs is confined to a footnote in Rizzi (1982). A\&P note that while their Clause Reduction hypothesis makes predictions about what a verb will do when it is assigned to a 'Trigger' or 'Non-trigger' class by a speaker, it "does not predict the class any particular verb will belong to for any individual speaker".

Taking stock of these formal accounts so far, both Rizzi (1982) and A\&P (1983) fall short of explaining how on one occasion the same matrix verbs can trigger $\mathrm{CC}$ and on others not, independent of the matrix verb being defined as a "Restructuring" or "Trigger" verb. It is precisely this optionality of CC that forms the basis of functional studies investigating exactly which variables are likely to drive the choices of acceptability of CC for Spanish speakers.

Rizzi (1982: 4) claims that the Restructuring Rule is restricted to matrices in three "syntactically and semantically rather homogenous" classes of matrix, namely modals, aspectuals and aspectuals containing motion verbs. A\&P (1983) report that the same three groups are those, which are most likely to promote Clause Reduction. Wurmbrand's (2003: 343) summary notes that the same three are proposed by Napoli (1981) for Italian, Picallo (1985) for Catalan and Zagona (1982) for Spanish, among others. The discussion provided by formal accounts therefore suggests that $\mathrm{CC}$ will occur in matrices which are modal, aspectual or in verbs of motion that express aspectual nuances. Cinque (2001: 138) seriously refines this type of grouping, which he claims relies on "arbitrary lexical 
specification, or arbitrary semantic condition". He claims that the link is nonarbitrary and that verbs in these groups correspond to functional heads in the proposed universal hierarchy in Cinque (1999). He therefore proposes that a rigid cline of 'restructurability' (our term) occurs within the three groups, which would manifest in transparency effects, such as $\mathrm{CC}$, in Italian. This would go some way to explaining which verbs could potentially allow $\mathrm{CC}$, yet does $\mathrm{CC}$ occur in verbal-complexes headed solely by matrix verbs that can be classified within these three groups? How does this explanation account for variation within the three classes of matrix verbs? For example, how can it explain haber, 'have', structures which express perfect aspect and categorically accept $\mathrm{CC}$, and at the same time aspectual continuar, 'continue', which despite allowing $\mathrm{CC}$, does not trigger a fixed clitic placement? A priori, it would seem that the nature of these formal accounts could be too categorical in nature to truly account for the variation attested.

An overview of the formal discussion of CC would not be complete without mentioning Kayne (1989), Roberts (1997) and den Dikken \& Blasco (2007). These provide detailed syntactic analyses of the process of Restructuring and the mechanics of CC. However, it is worth reiterating that what any of these formal accounts have failed to capture is the inherent optionality of CC in these types of languages. The lack of the ability of these accounts to predict these options highlights the fact that these proposals leave many questions surrounding this type of CC unanswered. What is it about these internal mechanisms that would trigger climbing on some occasions and on others not? Moreover, by the nature of Minimalist objectives, it seems that any grammatical feature that inherently has two spell out options is difficult to explain while adhering to the theoretical goals of this particular framework.

Turning our attention now to functional accounts, Myhill (1988: 354-355) proposes a link between the grammaticalisation of a matrix and its ability to allow CC. Discussing Bybee's (1985) cross-linguistic study on inflection, he hypothesises that "the meanings most likely to be represented grammatically through inflections are also the meanings most likely to trigger a synchronic grammaticalisation process such as the restructuring process associated with CC" (Myhill, 1988: 354). He proposes, based on Bybee's (1985) results, that matrices with 'progressive' aspect (ir+gerund, estar +gerund, 'go' and 'be' +gerund respectively) and then ir a, 'be going to' (as a future marking), are those which will give the highest acceptability of CC, which is borne out in his results (Myhill, 1988: 355). This reflects Napoli's (1981: 882) suggestion that various degrees of "conceptual unity" exist between the "(near) juxtaposition" of matrix and embedded verbs allowing CC, of the same type that exists between an auxiliary and a main verb. It follows that clitics are even more likely to climb if the matrix is an auxiliary such as estar, 'be', or in the case of ir a, 'be going to'. However, do these accounts allow us to capture the optionality displayed? A priori, it could be argued that this is the case, because the cline means that we are discussing likelihood for CC and not categorical, or even binary groupings.

Davies (1995) also proposes a semantically gradient approach to ordering verbs which allow CC. In his study 32 verbs were selected from corpora and ordered according to their relative acceptability of $\mathrm{CC}$, with the results showing a continuum-like spread of acceptability across the 32 matrices. His verb-by-verb 
approach has the merit of outlining those matrices which allow $\mathrm{CC}$ that are not captured by the strict groupings; for example saber, 'know/know how', is listed as having a higher acceptability on average $(33 \%)$ for $\mathrm{CC}$ than some modals (e.g. necesitar, 'need', and deber, 'must', both 20\%) and verbs which encode aspectual information (e.g. comenzar a, 'start to', and dejar de, 'stop', both at 25\%). Another analysis within this framework is Gudmestad (2005), which focuses on only two verbs, ir, 'go' (and its various permutations e.g. ir a, ir+gerund, 'be going to' and 'go'+gerund, respectively), and querer, 'want', with results indicating that distinct weightings of internal and external factors are responsible for $\mathrm{CC}$ acceptability for each matrix, in turn suggesting that the acceptability of $\mathrm{CC}$ must be examined on a verb-by-verb basis. The results from her study highlight to us the importance of considering more than just one possible influencing factor. Within functional perspectives, this idea suggests that the degree of grammaticalisation is dependent on various elements. Under formal accounts, this mixed-dependency situation would become much more difficult to encapsulate.

\subsubsection{Tense of Matrix and its Effect on the Level of Grammaticalisation}

Gudmestad (2005: 3) comments that the effect of matrix tense on CC is understudied in previous literature. The author notes that ir a, 'be going to', and ir +gerund, 'go'+gerund, constitute a special case in that grammaticalised future and progressive readings are inevitable in the present tense - they are interpreted as bleached of the semantic reading of motion. In Myhill's (1988) study, these grammaticalised forms are regarded as auxiliary (basic) meanings which are likely to favour CC. However, Gudmestad (2005: 4) argues that (5) represents a counterexample to Myhill (1989: 237), where ir, 'go', in the preterite is read as maintaining semantic meaning of motion rather than functioning as a temporal auxiliary:

$$
\begin{aligned}
& \text { yo fui a decirle } \\
& \text { I go.PAST.1SG to tell.INFIN-CL.IO.3SG } \\
& \text { 'I went to tell him.' }
\end{aligned}
$$

Therefore, theoretically, $\mathrm{CC}$ is less likely to occur in (5) as the matrix is not fully grammaticalised in the past tense and thereby maintains its (lexical) motion reading. In this sense, her claim is that the tense of matrix verb ir, ' $g o$ ', is an indicator of $\mathrm{CC}$ because the tense has a direct impact on how monoclausal the verbal complex becomes. Nonetheless, results from Gudmestad's (2005) study showed that tense was not a significant predictor of CC in Caracas Spanish, but it was noted that more research is needed to determine the effects of tense on the readings of auxiliaries and CC acceptability. Contrastingly, Sinnott \& Smith (2007) record that the tense of the matrix was the most significant predictor of $\mathrm{CC}$ in the Spanish of Bogota, but, similar to Gudmestad's (2005) reports, tense was not significant at all for their data from Madrid. Functional accounts to date, therefore, remain inconclusive as to what extent tense is influential on $\mathrm{CC}$ incidence, though, they may indicate that there is a possibility of some diatopic variation.

According to den Dikken \& Blasco's (2007) formal account, Tense does have some bearing on $\mathrm{CC}$ incidence cross-linguistically, as the matrix verb must be marked for Tense in order to attract the infinitival verbal complex, thereby 
allowing the clitic to move up to SpecTP. Cyrino (2010a) and (2010b) and references therein also propose an explanation for the lack of $\mathrm{CC}$ in Brazilian Portuguese, in (2010a) comparing it with optional CC in European Portuguese, which centrally involves the role of Tense ( $\mathrm{T}$ and $\mathrm{C}-\mathrm{T})$. Therefore, from a formal perspective, under Minimalist theories, Tense does play a role in the climbing of the clitic, but the only condition on tense, is that the embedded verb is non-finite (but not a past participle). Furthermore, there is no explanation as to why Tense would affect the optionality surrounding $\mathrm{CC}$, let alone tense. It remains unexplained from a formal perspective why tense should be involved in affecting the likelihood of CC.

\subsubsection{Mood of Matrix}

To the best of our knowledge, no previous study has investigated the effect of the subjunctive on $\mathrm{CC}$, where the restructuring verb is formed in the subjunctive, without functioning as a polite or negative command (see den Dikken \& Blasco 2007). A proposed line of investigation here would be CC incidence in a verbal complex headed by a matrix verb conjugated in the subjunctive and selecting a non-finite complement with a clitic, as shown in (6):

$$
\begin{aligned}
& \text { El plan de sostenibilidad es muy ambicioso y dudo que el } \\
& \text { the plan of sustainability be.3SG very ambitious and doubt.1SG that the } \\
& \text { presidente vaya implementándoloritor. con mucho éxito. } \\
& \text { president go.SUBJ.3G implement.GER-CL.DO.3SG with much success } \\
& \text { 'The sustainability plan is very ambitious and I doubt that the president is } \\
& \text { implementing it with much success.' }
\end{aligned}
$$

The limited amount of current published research on this perspective, therefore, needs to be addressed, at least for the purpose of elimination and/or description. As with the difficulty in formally explaining the influence of tense on $\mathrm{CC}$, formally it is unclear why subjunctive use would either promote or deter CC.

\subsubsection{Form of Non-Finite Complement}

Although accounts of $\mathrm{CC}$ tend to look at complexes where the embedded verb is in the infinitive, other non-finite forms may be seen as variables on the impact of CC. Empirically, embedded gerunds are shown to strongly promote CC based on Myhill's (1988) findings of the progressive aspect being most likely to promote climbing, a result which is confirmed in Iglesias (2012). Formally, there seems to be no obvious unifying explanation for this, in a similar vein to the difficulty in explaining an influence on $\mathrm{CC}$ because of tense or subjunctive (although see Emonds (1999: 313) for a formal account of CC in structures with embedded gerunds). Functionally, it could be argued that Myhill's (1988) investigations revealed high $\mathrm{CC}$ incidence in already highly grammaticalised structures, namely with auxiliaries which select gerund complements. The question is: is CC equally as highly likely to occur in verbal complexes headed by matrix verbs that are not auxiliaries as in those which are if both select an embedded verb in gerund form, 
such as progressive ir and estar ('to go' and 'to be'), and continuar and seguir ('continue' and/or 'carry on')?

\subsubsection{Clitic Make- Up}

Considering the clitic itself as a variable for $\mathrm{CC}$ incidence/optionality, here we outline three different factors: clitic $\varphi$-features, clitic animacy/topicality and single vs. multiple clitics. Formally, why the properties of the clitic itself should bear any influence on $\mathrm{CC}$ would remain to be explained. However, the empirical data in the literature may prove that this route forms a valid line of investigation.

Gudmestad (2005) finds that clitic $\varphi$-features, such as the person, number and gender of the clitic, constrain $\mathrm{CC}$. Her model reveals a certain level of variation as to when $\mathrm{CC}$ will occur with the matrix verb ir, 'go', dependent on the clitic person and, principally, the clitic number:

$$
\begin{aligned}
& \text { Person hierarchy with ir } \\
& 2^{\text {nd }} \text { person }(98.6 \%)>1^{\text {st }} \text { person }(93.9 \%)>3^{\text {rd }} \text { person }(90.0 \%)
\end{aligned}
$$

$$
\begin{aligned}
& \text { Clitic number hierarchy with ir } \\
& \text { singular }(95.7 \%)>\text { plural }(78.6 \%) \\
& \text { Gudmestad (2005: 6-7) }
\end{aligned}
$$

$2^{\text {nd }}$ person clitics are marginally more likely to climb than $1^{\text {st }}$ person clitics, and $1^{\text {st }}$ person clitics are also more likely to climb than $3^{\text {rd }}$ person ones. However, the values in (7) are so close that it is still difficult to establish a predictive relationship with regard to $\mathrm{CC}$ and the person value of the clitic. Similarly, she shows that singular clitics have a higher probability of climbing than plural ones, presenting statistics that potentially have a little more predictive power than those for clitic person. The gender of the clitic was not investigated. Again, this variation is not easy to capture within formal models and, functionally, the explanation does not become any clearer. It is worth noting that despite Gudmestad's (2005) apparently sturdy statistical analysis, the results are taken from a corpus in verbal complexes headed only by the verb ir ('go'). ${ }^{3}$

Turning our attention now to the effect of the animacy/topicality of the clitic on CC, Myhill (1989: 242) proposes an 'Animacy Hierarchy' for the referent person and number of the clitic and suggests that those clitics which are more animate on the scale are more likely to climb. Gudmestad (2005) claims that $i r$, 'go', proved to be linguistically constrained by animacy, as shown in (9):

2 Conversely, enclisis with embedded participles is strictly forbidden in Spanish (Emonds (1999:319) inter alios), presumably, from a functional perspective, because the degree of grammaticalisation is such that the only available position is the preverbal one.

3 Could a possible basis for the clitic person statistics alternatively be found in the phonological weight of the clitic? Plural clitics have one phoneme more in most varieties, namely voiceless alveolar fricative /s/ (which may receive aspirated pronunciations and in some varieties elision). Could it be a change in process in order to differentiate singular and plural clitics? We leave a comprehensive study of this up to further work. 
(9) Animacy Hierarchy with ir

Inanimate $(96.2 \%)>$ animate $(89.6 \%)$

The four-way characterisation is captured in Figure 1.

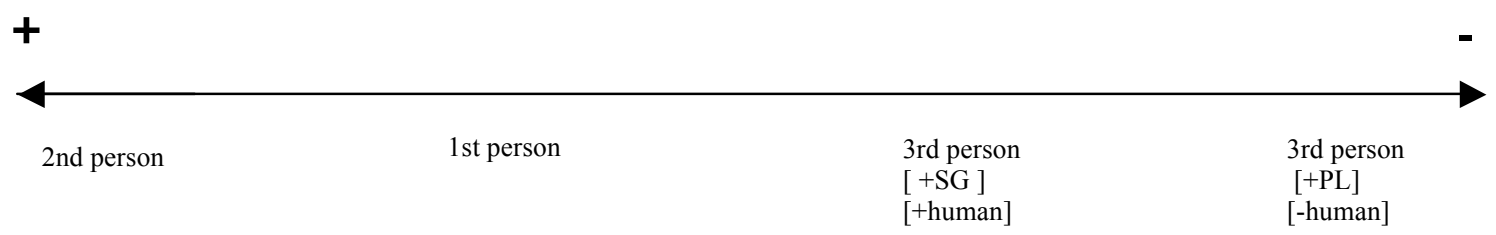

Figure 1. A representation of Myhill's (1992: 224) proposed Topicality Hierarchy and his earlier (1989: 242) Animacy Hierarchy

He notes that clitic animacy must be graded relative to the subject of the matrix verb, where clitics more animate than the subject are more likely to climb; thus, according to this classification, $\mathrm{CC}$ is more likely to occur in (10) than in (11), despite me occurring high on the animacy hierarchy.

Juan quiere verte mañana.

john want.3SG see.INFIN-CL.DO.2SG tomorrow

'Juan wants to see you tomorrow.'

(11) Debes avisarme antes de que te vayas.

must.2SG warn.INFIN-CL.DO.1SG before of that you go.SUBJ.2SG

'You must let me know before you go.'

Furthermore, a link is proposed between the animacy/person of the clitic and its topicality status, whereby the more animate $2^{\text {nd }}$ and $1^{\text {st }}$ persons are more topical in discourse, and, therefore, more likely to be preposed (i.e. climbed) in Spanish. By substituting old information in the discourse, clitics are indisputably topics and, furthermore, it is widely accepted that information structure features, such as topic, are significant in constraining Modern Spanish word order (Zubizarreta 1998, inter alios). Thus, it is claimed that information structure and, more specifically, topicality may affect the spell-out of clitics (Leal de Andrade 2010). Indeed, Myhill's later (1992) work comments a possible relative importance in the discourse value of the clitic object pronoun referent to that of the subject for CC. His (1992) proposed hierarchy is one of topicality, but ultimately maintains the shape of his (1989) cline for relative animacy (Fig. 1). This makes a very interesting line of enquiry as it may offer an alternative formal explanation to the semantics of the matrix verb. Namely, what is more of interest here is the semantics not only of the matrix verb, but also the semantic/syntactic relationship between the matrix verb, clitic and possibly other material in the clause. This explanation would be found at the formal/functional interface.

However, Myhill (1988: 360) notes “... that the relative topicality of the subject and the clitic is secondary in importance to the semantic characteristics of the finite verb" [our emphasis]. Davies' (1995) results for written and spoken data 
confirm Myhill's (1989: 242) animacy proposition, though it is not mentioned whether or not the clitics are coded as relative to the subject of the matrix. In Gudmestad (2005) inanimate clitics were reported as being more likely to climb than animate clitics, contra Myhill; it is commented, however, that the differences may be explained by differences in data coding, namely the (non)separation of anaphoric vs non-anaphoric se, which would affect animacy readings.

Finally, Davies (1995) investigates the impact of the number of clitics on CC. He reviews work on $\mathrm{CC}$ in instances when there are multiple clitics generated by the lower verb, namely clitic clusters. His claim is that clitic clusters are increasingly understudied under a general assumption that they are likely to behave in the same way as single clitics. His findings show, however, that multiple clitics are significantly more likely to climb in both the written and spoken data. Formally, these findings are, on face value, almost impossible to explain. Functionally, the only reason, a priori, would be that of phonological weight. However, most importantly, neither a formal or functional account could explain the optionality, as forms the majority of the critiques of the current theories.

\subsubsection{Preceding Material}

Davies (1995) notes that, as yet, no one has studied the impact or effect of para/hypotaxis on $\mathrm{CC}$, that is to say whether or not the verbal complex featuring $\mathrm{CC}$ is part of a coordinating or subordinating conjunction. He claims that evidence from Old and Middle Spanish (Ramsden 1963, Keniston 1937) shows subordination favouring $\mathrm{CC}$, whereas coordination does not. He claims that no research has been undertaken on this for modern Spanish, and although it was initially attempted in Ayres (2014: 13), it awaits its own investigation proper.

\subsubsection{Null Subject Parameter}

$\mathrm{CC}$ is often described, under generativist terms, as being a correlation of the Null Subject (NS) status of a language (Kayne 1989, Rodríguez Mondoñedo et al. 2004). Assuming this relationship to be correct, then we cannot ignore one side of the same coin. Unlike the functional triggers discussed above, the connection with the Null Subject Language (NSL) status aims to provide a theoretical explanation as to why the syntactic mechanism of what happens whenever CC is triggered is permitted by the speakers' I-language, i.e. how the clitic is able to escape the domain of the embedded verb within which it is generated.

Kayne's (1989) classic work under the Principles \& Parameters framework details how the INFL setting, either strong or weak in any given language, determines the setting of the Null Subject Parameter (NSP). In NSLs, INFL is strong, thereby causing the VP to lose its barrierhood and enabling clitics to climb out of the lower clause. In Minimalist terms this is captured by way of a defective restructuring domain. However, according to den Dikken \& Blasco (2007) and Beukema \& Coopman (1989), this only accounts for one type of CC, namely that which occurs via XP-movement and affects aspectual verbs (e.g., ir, 'go', and venir, 'come' (den Dikken \& Blasco, 2007: 9)). ${ }^{4}$ A defective T means that VP-

The other type, which affects matrix verbs, which take CP-complements such as quiero (Rooryck 2000), is via head-to-head movement. In these cases, there is no relation between the tenses of the verbs and CC occurs regardless of whether the matrix clause is specified for Tense (den Dikken \& Blasco 2007: 9). 
raising will occur, due to T being attracted to SpecTP, à la Kayne (1989), whereby temporal coindexation between the verbs is created. With this VP-raising, the clitic moves into the matrix $\mathrm{AGR}_{\mathrm{S}}$ domain (den Dikken \& Blasco 2007) and is spelled out in the climbed position. Therefore, considering all these formal accounts, it is important to test ArgSp varieties for the NSP. However, triggers of the optionality as opposed to the climbing of the clitic itself remain underdiscussed.

\subsection{Language-External Variables}

\subsubsection{Diatopic Variation}

Despite the geographical expanse of the Spanish-speaking world, very few studies of CC have documented diatopic variation. Although Davies (1995) uses data from ten countries he reports minimal variation; the variation which does exist is accounted for on a register level (see §2.2.3). On the other hand, Sinnott \& Smith (2007) find that the Spanish of Madrid and that of Bogotá differ in their acceptance of $\mathrm{CC}$, with $\mathrm{CC}$ more common in Madrid, and the triggers of CC varying between the two varieties (see §2.1.2). Bosque et al. (2009: 1238) also provide some information on diatopic variation in $\mathrm{CC}$ in spoken Peninsular varieties, mentioning that $\mathrm{CC}$ with haber que, 'have to'/'must', is registered in certain areas of Castilla and northern regions of Spain. Undoubtedly, there is some incentive to examine the regional differences in acceptability of $\mathrm{CC}$ more fully, following Sinnott \& Smith's (2007: 1) warning against considering Spanish "an undifferentiated whole".

\subsubsection{Diastratic Variation}

Gudmestad (2005) is the first to investigate sociolinguistic effects on CC. She finds that $\mathrm{CC}$ increases inversely to socioeconomic status (henceforth SES), although this is only significant for querer, 'want', thus inviting a verb-by-verb approach to analysis. According to Gudmestad (2005) this is not indication of a change in process (see Labov 1972) as the results have remained stable across time when compared to Davies' (1995) results from earlier corpora. CC was significantly more common in women in Gudmestad (2005), but only with querer, 'want'; again this is a "stable difference" which may even be unreliable given the small number of querer, 'want', tokens tested. Age was not a significant predictor of CC in Gudmestad's (2005) study, which again could point to an important level of stability.

\subsubsection{Diaphasic and Diamesic Variation}

Davies (1995: 372) argues that the greatest degree of variation is seen at the register level. His corpus study shows that $\mathrm{CC}$ is much more common on average in spoken Spanish than written, concluding that CC is therefore a feature of 'popular' informal modern Spanish. Iglesias (2012) compares more closely the effect of the spoken vs. written medium on $\mathrm{CC}$ in examining idiolectal corpora, which he claims is methodologically more sound; his results show, also, that CC is more of a feature of spoken, rather than written, Spanish. Within formal accounts, as has been stated already, Rizzi (1982) proposed that the assignment of verbs to the three Restructuring classes is also idiolectal. 


\subsection{Summary}

Table 1 provides a summary of the factors influencing $\mathrm{CC}$ detailed in the existing literature which are outlined above.

Promotes Tested

CC Here?
Why?/Why not?

Current

formal/functional

account exists?

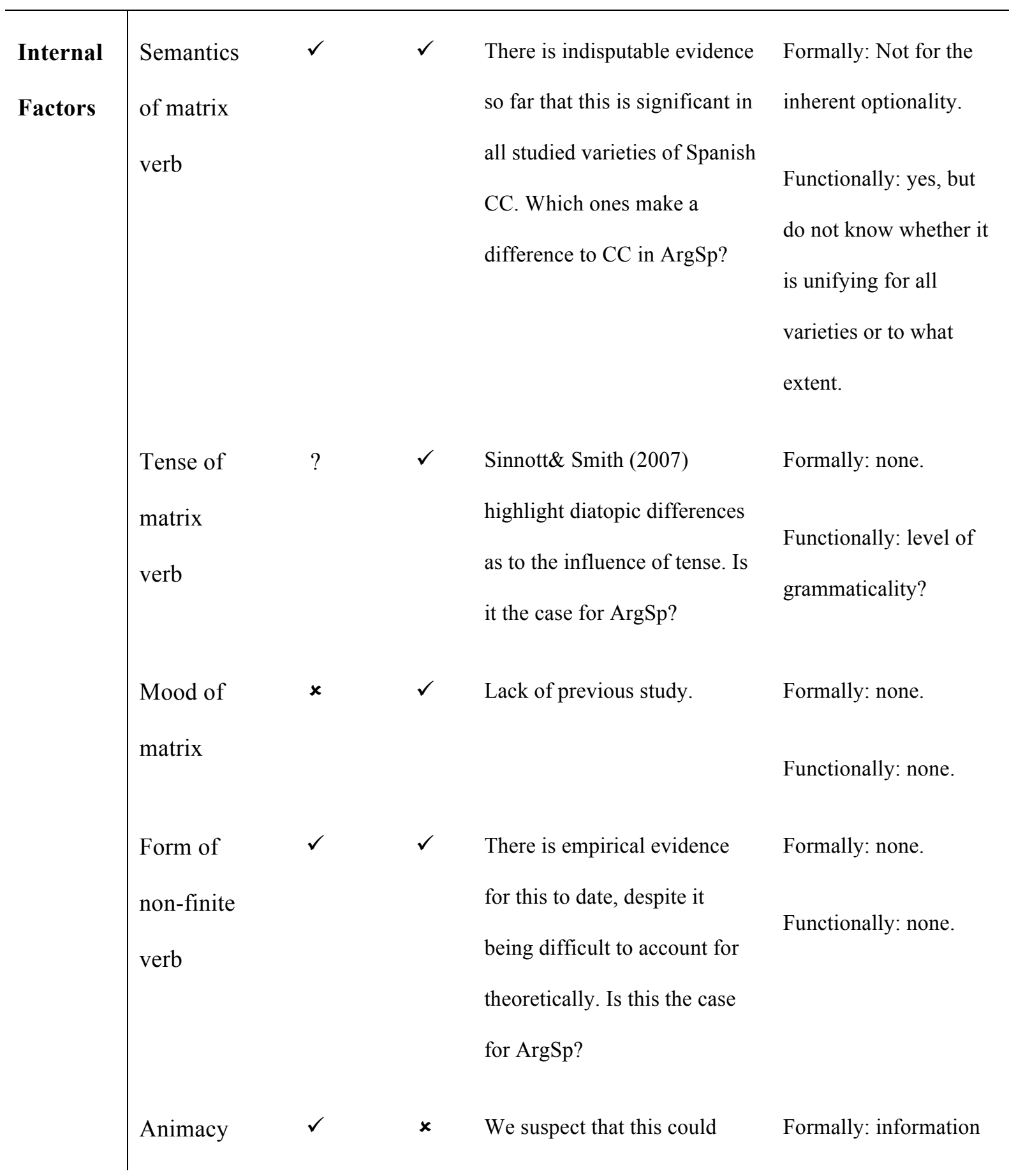




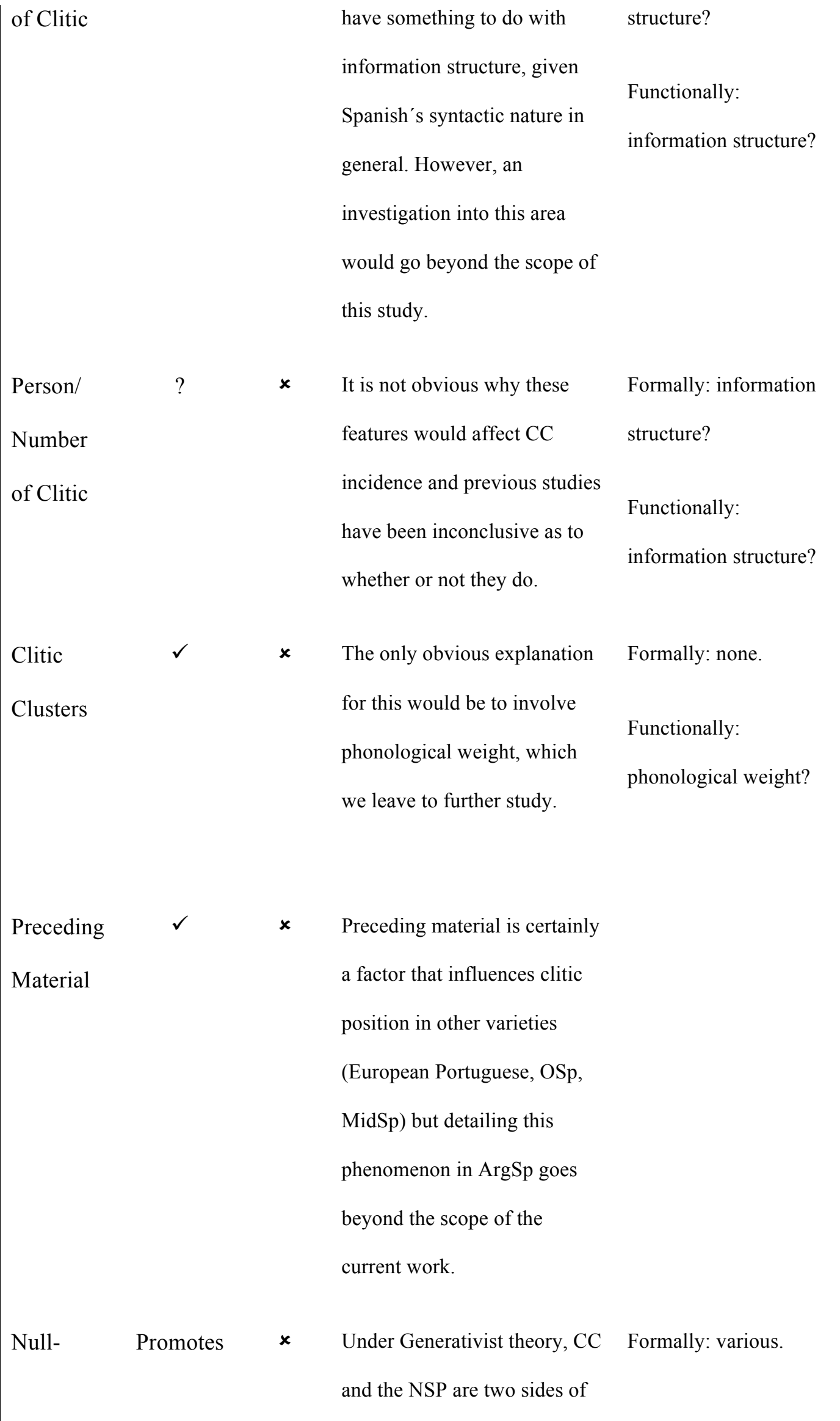




\begin{tabular}{|c|c|c|c|c|c|}
\hline & $\begin{array}{l}\text { subject } \\
\text { language } \\
\text { status }\end{array}$ & optional & & $\begin{array}{l}\text { the same coin. However, } \\
\text { investigating the NSP in } \\
\text { ArgSp would not provide us } \\
\text { with an explanation for all the } \\
\text { facts, including the inherent } \\
\text { optionality surrounding the } \\
\text { phenomenon. }\end{array}$ & 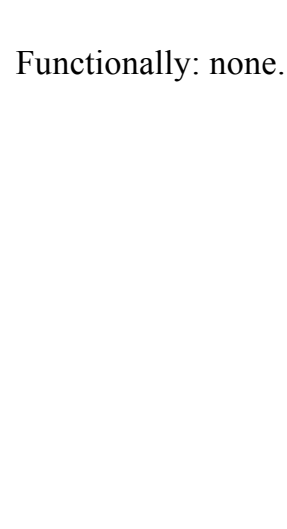 \\
\hline $\begin{array}{l}\text { External } \\
\text { Factors }\end{array}$ & $\begin{array}{l}\text { Diatopic } \\
\text { Variation }\end{array}$ & $?$ & $\checkmark$ & $\begin{array}{l}\text { This feature of ArgSp has not } \\
\text { been reported on so far, to the } \\
\text { best of our knowledge. }\end{array}$ & \\
\hline & $\begin{array}{l}\text { Diastratic } \\
\text { Variation }\end{array}$ & $?$ & $\checkmark$ & $\begin{array}{l}\text { As far as we know, only } \\
\text { Gudmestad (2005) has } \\
\text { provided data on possible } \\
\text { sociological factors that are } \\
\text { often indicative of change, or } \\
\text { stability, within a language. }\end{array}$ & \\
\hline & $\begin{array}{l}\text { Diamesic } \\
\text { Variation }\end{array}$ & $\checkmark$ & $x$ & $\begin{array}{l}\text { Previous studies have recently } \\
\text { provided clear evidence on the } \\
\text { spoken vs. written distinction } \\
\text { regarding CC incidence. }\end{array}$ & \\
\hline
\end{tabular}

Table 1. Summary of triggers outlined in previous study of CC, including triggers investigated in the present study

For our own line of study, given the literature review, it is safe to say that formal accounts fall short of accounting for all of the data so far. Namely, it is proving very difficult under current theory to explain the optionality of CC in type (a) languages. Functional accounts have highlighted diatopic differences within the optionality, although it is possible that they are no closer to providing an explanation for the same optionality. Therefore, it is important for us to contribute to pushing forward the understanding of this linguistic phenomenon within a set of under-reported Spanish varieties, namely ArgSp, by looking at data in the areas detailed in Table 1 for possible internal triggers. 


\section{Data Collection in Argentinean Spanish}

For the purposes of this study, data from two fieldtrips were used: (i) in 2011(see Whimpanny 2012), 19 native speakers were sought from the cities of: Buenos Aires and Mar del Plata, which under Hualde's (2005) analysis, constitute the River Plate variety (RP); Mendoza and San Luis, in order to examine the Cuyo Region variety $(\mathrm{Cu})$, and; Cordoba, composing the Central variety (C). (ii) in 2013 (see Ayres 2014), 47 native speakers were tested in: Buenos Aires province and Capital Federal (BsAs); in Puerto Madryn and Trelew (in Northern Coastal Patagonia) (CP); in the Lake District (LD) along the border between Rio Negro and Neuquen; and in Santa Cruz and southern Chubut in Southern Patagonia (SP).

\subsection{Methodology of Present Study}

In order to test for $\mathrm{CC}$ acceptability in ArgSp, written questionnaires were compiled and subsequently presented to the speakers for grammaticality judgments. Whenever possible the questionnaires were conducted orally to circumvent high register connotations especially with less educated speakers. Acceptability of $\mathrm{CC}$ was tested by presenting pairs of configurations that consisted of $[+\mathrm{CC}]$ and $[-\mathrm{CC}]$ versions across a range of restructuring matrix verb complexes, which selected either infinitives or gerunds, as detailed in \$3.2. Speakers gave an acceptability judgment for each of the examples, both $[+\mathrm{CC}]$ and [-CC] forms, based on a tripartite system:

(12) + $\quad$ Lo digo así, me gusta (2011);

1 Está bien (2013)

(13) ? No lo digo pero lo entiendo (2011);

$2 \quad$ No estoy seguro/a, puede ser (2013)

(14) * No me gusta (2011);

3 Está malo $(2013)^{5}$

Emphasis was placed on the requirement for instinctive answers as opposed to the speaker's perception of what would be correct. Both questionnaires had a randomised order and provided the speakers with the opportunity to record semantically equivalent alternatives to each example they were presented with. Only native ArgSp speakers were considered. Whether or not the speaker knew any other languages as L1 or L2 was noted in order to track contact induced change. Informants were asked where they were born and where they had spent most of their lives so that we were able to monitor diatopic

$5 \quad$ A reviewer pointed out that "está malo" may have confused some informants. Although, obviously not ideal, the effect on the grammaticality judgment should not differ in essence - especially given the variation in the results - because we only analysed the "positive" results (1 -“está bien"). At worst, some of the positive results may have been excluded, but the results would not misguide us entirely. 
variation tightly. Both male and female speakers were used, mainly across the age range 20-50 for the 2011 survey and informants from 16 to over-55 for the 2013 one. Figure 2 maps the locations and number of speakers consulted in each location.

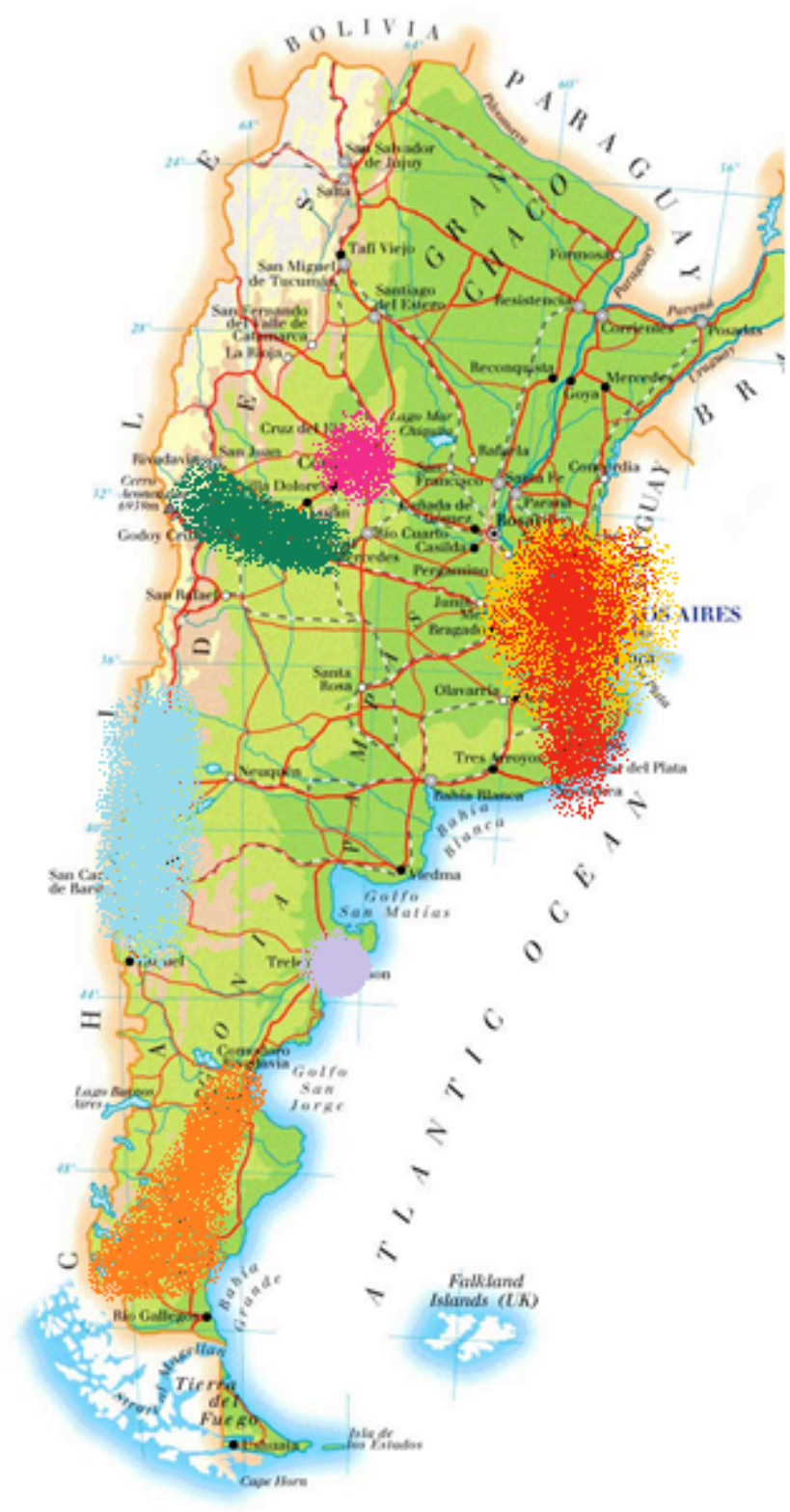

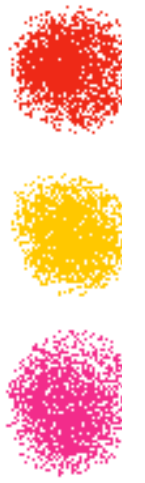

River Plate (5 speakers)

- Data collected from Buenos

Aires \& Mar Del Plata (2011)

Buenos Aires Province (8 speakers) - Data collected from Capital Federal (2013)

Central Region (3 speakers)

- Data collected from Córdoba (2011)

\section{Cuyo Region (11 speakers)}

- Data collected from Mendoza and San Luis (2011)

Lake District (7 speakers)

- Data collected from San

Carlos de Bariloche, San

Martin de los Andes and Villa de la Angostura (2013)

\section{Coastal Patagonia (3} speakers) - Data collected from Puerto Madryn (2013)

\section{Southern Patagonia (6} speakers)

- Data collected from El Calafate (2013)

Figure 2. Map of data collection in Argentina. Image taken from http://en.18dao.net/Map/Argentina and modified

\subsection{Composition of the Questionnaires}

Five matrices were common to both the 2011 and the 2013 data collection: comenzar $a$, 'start to', empezar a, 'start to', ir a, 'be going to', ir+gerund, 'go'+gerund, and estar+gerund, 'be'+gerund. The 2011 questionnaire selected the following additional matrix verbs, thereby bringing the total number of 
constructions tested to $12:^{6}$ poder, 'be able to', querer, 'want', tener que, 'have to', haber que, 'have to'/'must', necesitar, 'need to' and deber, 'must' (see Whimpanny (2012: 21-23) for a detailed discussion of the selection criteria for the matrix constructions in the 2011 study). Constructions tested in the 2013 main study were headed by: continuar $a$, 'continue to', continuar+gerund, 'continue'+gerund, and seguir+gerund, 'carry on'+gerund, in addition to the five matrices which were tested in both studies (see Ayres 2014: 13).

All CC examples tested the phenomenon mainly with direct object clitics only, and once each with impersonal se and passive se in 2011. Care was taken to minimise the linguistic variables, therefore canonical word order was used, in an attempt to ensure speakers would not give judgments on any other aspect of the grammar. Pilot studies were meticulously conducted in order to rule this out and also to standardise the questionnaire further. For instance, (i) in 2011 a pilot study was carried out with each speaker in order to identify their clitic usage so as to avoid grammaticality judgments potentially depicting leista/loista/laísta attitudes; incidentally, all speakers displayed Standard clitic usage; (ii) in the 2013 data collection, it was noted in the first and second pilot (Ayres 2014: 12-13) that speakers would occasionally respond to the affective content of each sentence, thus judging a sentence as "malo" where the content was negative, despite the whole phrase being grammatically acceptable (see footnote 5).

\section{Discussion of Empirical Results from the Perspective of Internal Triggers}

Here we analyse our data according to some of the variables discussed in $\S 2$, namely the matrix verb semantics, TAM of the matrix, animacy/topicality of the clitic, and the null-subject status of ArgSp. It goes without saying that further study into the effect on $\mathrm{CC}$ in ArgSp of the other internal variables (number of clitics in the cluster, $\varphi$-features of the clitic, as well as preceding material) as a trigger would be most welcomed.

Focusing our attention first on the semantics of the matrix verb (\$2.1.1), there is an undeniable link between the restructuring ability of a matrix verb (Wurmbrand 2001) and an element of likelihood of the clitic to climb in ArgSp (Whimpanny 2012, Ayres 2014) and also in other varieties of Spanish (Davies 1995, Myhill 1992), including SPSp (Butt \& Benjamin 2004, inter alios). However, the nature of the correlation is not easily deciphered. Myhill (1992: 218 ) comments that there is not a categorical relationship (our emphasis) between monoclausality and the frequency of CC. Here, we aim to decide if the link between $\mathrm{CC}$ and this variable is in any way predictable. Does a monoclausalbiclausal cline exist for CC? Consider Table 2:

6 Poder, 'be able to', was tested twice in 2011, once with a direct object pronoun clitic and once with the impersonal clitic se. 


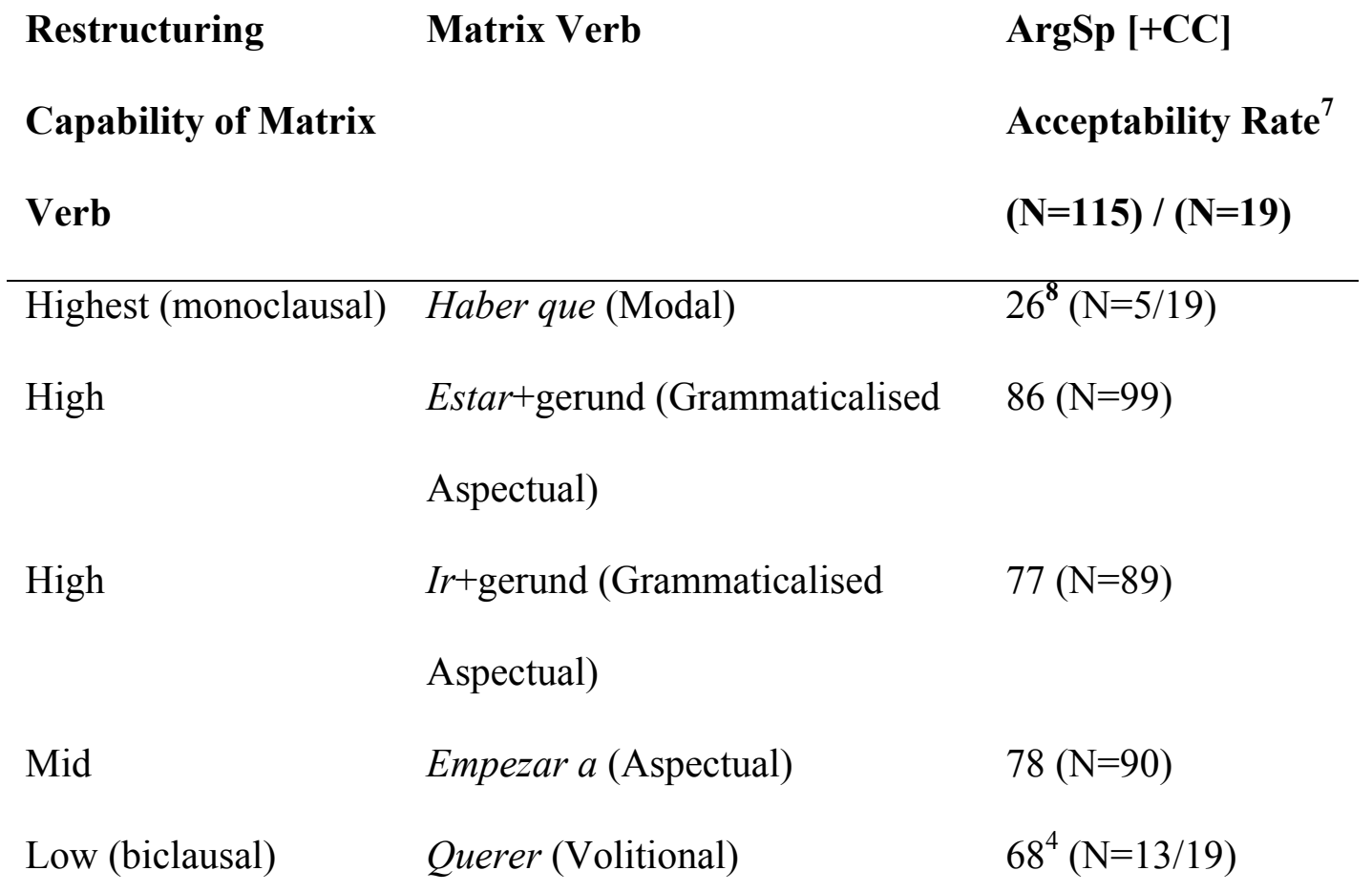

Table 2. Percentage acceptability of $\mathrm{CC}$ with verbs with different restructuring capabilities

Here we have selected these verbs to provide a snapshot of the statistics along a monoclausality cline. We notice that the most monoclausal construction, headed by modal verb haber que, 'have to'/'must', received a $26 \%$ acceptability rate, and the most biclausal construction, headed by volitional verb querer, 'want', accepted CC in $68 \%$ of cases. In between these two ends of the supposed monoclausal-biclausal cline, we report a variety of (relatively higher) statistics for CC acceptability with aspectual constructions. Despite previous works (Davies 1995, Cinque 2002) having detailed a continuum-like spread of acceptability across the matrix verbs tested, here, it is clear that the percentage acceptability rates returned from the interviews do not coincide with the order of the matrix verbs distributed along the monoclausality cline. Furthermore, permutations recorded in comparison with SPSp have not spread strictly along this expected cline of monoclausality (see $\S 6$ and, specifically, the discussion of Table 12), therefore putting into question the likelihood of the degree of grammaticalisation of the matrix alone as the trigger.

In addition to the restructuring/grammaticalisation effects, the TAM (\$2.1.2 and §2.1.3) of the matrix verb was varied to analyse this potential trigger, as was the form of the embedded non-finite complement that the matrix verb selects (§2.1.4). Consider Table 3:

\footnotetext{
7 Total number of tokens in 2011 and 2013 studies combined is 115 . Total number of tokens in 2011 only is 19.

82011 data only.
} 


\begin{tabular}{lcccc} 
Matrix & Present $(\mathrm{N}=42)$ & Preterite & Perfect & Subjunctive \\
& & $(\mathrm{N}=42)$ & $(\mathrm{N}=42)$ & $(\mathrm{N}=\mathbf{4 2})$ \\
\hline estar+gerund & $100(\mathrm{~N}=42)$ & $69(\mathrm{~N}=29)$ & $88(\mathrm{~N}=37)$ & $83(\mathrm{~N}=35)$ \\
continuar+gerund & $95(\mathrm{~N}=40)$ & $74(\mathrm{~N}=31)$ & $67(\mathrm{~N}=28)$ & $98(\mathrm{~N}=41)$ \\
ir $\boldsymbol{a}$ & $93(\mathrm{~N}=39)$ & $93(\mathrm{~N}=39)$ & $62(\mathrm{~N}=26)$ & $93(\mathrm{~N}=39)$ \\
seguir+gerund & $88(\mathrm{~N}=37)$ & $76(\mathrm{~N}=32)$ & $81(\mathrm{~N}=34)$ & $95(\mathrm{~N}=40)$ \\
ir+gerund & $86(\mathrm{~N}=36)$ & $83(\mathrm{~N}=35)$ & $90(\mathrm{~N}=38)$ & $74(\mathrm{~N}=28)$ \\
comenzar a & $86(\mathrm{~N}=36)$ & $95(\mathrm{~N}=40)$ & $79(\mathrm{~N}=33)$ & $88(\mathrm{~N}=37)$ \\
empezar $\boldsymbol{a}$ & $67(\mathrm{~N}=28)$ & $81(\mathrm{~N}=34)$ & $83(\mathrm{~N}=35)$ & $86(\mathrm{~N}=36)$ \\
\hline Overall $(\mathrm{N}=\mathbf{2 9 4})$ & $88(\mathrm{~N}=258)$ & $82(\mathrm{~N}=240)$ & $79(\mathrm{~N}=231)$ & $87(\mathrm{~N}=256)$
\end{tabular}

Table 3. \% acceptability of CC across all matrix verbs tested against all internal variables in the 2013 study

Acceptability rates with matrix verb in present, preterite, and perfect tenses and subjunctive mood are presented. At first glance, the overall results for internal factors in this study indicate that: (i) embedded gerunds do not categorically allow more $\mathrm{CC}$ than embedded infinitives, and; (ii) matrix verbs are more likely to disfavour $\mathrm{CC}$ in the past tense than in the present, and furthermore are likely to disfavour the periphrastic perfect more than the preterite form. Moreover, results in Table 3 show that the effect of the subjunctive does not provide a solid prediction of the acceptability of $\mathrm{CC}$ with any given matrix tested in this study when compared to results from the same matrix in the present indicative. On the other hand, analyses of these internal variables on a verb-byverb basis, show that there is no definitive patterning of $\mathrm{CC}$ acceptability with these internal factors tested and therefore TAM is not a strong enough predictor of $C C$ to be considered conclusive in the present study.

Turning our attention now to the animacy/topicality of the clitic (\$2.1.5), Myhill's (1989, 1992) Animacy/Topicality Hierarchy described in Figure 1 is applied to (15) to test for the likelihood of animacy/topicality of the clitic as a trigger for $\mathrm{CC}$ :

a. Quiero llamarlo mañana (79\% preference in $\mathrm{ArgSp}$ ) want.1SG call.INF-CL.DO.MAS.3SG tomorrow'

'I want to call him tomorrow'

b. Lo quiero llamar mañana

CL.MAS.3SG want.1SG call.INF tomorrow

'I want to call him tomorrow' 
The hierarchy predicts that the non-climbed form in (15)a should be more frequent or preferred because the subject (1SG) is higher on the hierarchy than the clitic (3SG, [+human]). On this occasion, the hypothesis is borne out as the nonclimbed form (15)a received a 79\% preference rate. ${ }^{9}$ However, applying Myhill's hierarchy to (16) reveals that the hierarchy may not be relevant for ArgSp:

$$
\begin{aligned}
& \text { a. María debe regarlas todos los jueves } \\
& \text { mary must.3SG water.INFIN-CL.DO.FEM.3PL all the Thursdays } \\
& \text { 'Mary must water them every Thursday.' } \\
& \text { b. María las debe regar todos los } \\
& \text { mary CL.DO.FEM.3PL must.3SG water.INFIN all the } \\
& \text { jueves } \\
& \text { thursdays } \\
& \text { 'Mary must water them every Thursday.' }
\end{aligned}
$$

The hierarchy predicts that $[-\mathrm{CC}]$ in (16)a would be more frequent, or perhaps preferred, compared to $[+\mathrm{CC}]$ in $(16) \mathrm{b}$ because the subject (3SG, [+human]) appears higher on the hierarchy than the clitic object pronoun (3PL, [human]). However, the prediction was not borne out since $61 \%$ preferred the $[+\mathrm{CC}]$ form overall. In general, from examples (15) and (16) and their respective results, the conclusion is that Myhill's (1992) Topicality Hierarchy does not work categorically in ArgSp. Indeed, the failure of the hierarchy to capture the CC scenario in ArgSp does not definitively rule out the possibility of animacy or topicality influencing clitic placement in these varieties, though more rigorous testing would be required to be conclusive.

As for the NSP, despite some phonological erosion - which in other (Afro/Caribbean) Hispanic varieties is leading to the levelling of verbal conjugations, thereby increasing the frequency and distribution of the explicit spellout of subject pronouns and altering the NSP setting -ArgSp is stably a NSL (Whimpanny 2012). Distinctions between ArgSp conjugations are being conserved by the use of vos verbal forms, as opposed to tú conjugations which, with aspiration and subsequent morpho-phonological elision of the 2SG present indicative morphological marker, are being levelled for this verbal person conjugation in line with those for 3SG. As a cluster property of the NSP, it is expected that optional $\mathrm{CC}$ should remain a feature of ArgSp varieties. Consider Table 4: therefore, it was decided that rather than acceptability rates, preference rates would be used here to give an indication as to whether the hierarchy is applicable to our data. See Whimpanny (2012: 28) for preference results from 2011 empirical study. 


\section{Clustering Effect}

Results of NSP Cluster Effects Testings

in all ArgSp 2011 Varieties

Postverbal subjects?

Referential null subject?

Null expletive subject?

Other verb positions than just V2?

Unaltered verbal paradigm?

Infinitive movement?

Non-finite forms with distinct nominative

subjects?

Restructuring phenomena?

Table 4. NSP cluster effects results for average of all ArgSp varieties tested in 2011 (Whimpanny 2012)

Given that the majority of the cluster properties have been reported as still "intact" (indicated by the ticks in Table 4), we are presented with strong evidence that the NSL status of ArgSp has not changed. This result was to be expected owing to the verbal vos forms employed in the majority of the country, especially in the varieties tested. However, there are reports of alterations to the verbal paradigm, marked by a question mark in Table 4 . These are phonological in nature and, as stated before, crucially, do not induce levelling thereby preserving distinctions necessary to maintain the NSP setting. They are, however, indicative of the much reported, extensive phonological aspiration and erosion of word final and coda final $-\mathrm{s}$, Hualde (2005: 31).

Finally, Table 5 provides a summary of our results analysed according to the language-internal variables: 
Language-Internal Variable

Categorical Effect

on/Link with CC?

Semantics of

Matrix/grammaticalisation/monoclausality

Tense of Matrix

$\mathbf{x}$

Mood of Matrix

$\mathbf{x}$

Form of Non-Finite Complement

$\mathbf{x}$

Animacy

$x$

NSP

$\checkmark$ (as an NSL, ArgSp

maintains optional CC)

Table 5. Summary of which internal variables can be deemed a trigger for CC in $\operatorname{ArgSp}$

Table 5 here shows that although ArgSp is an NSL and thereby affords optional $\mathrm{CC}$, there is no clear single internal trigger that conclusively determines the availability of $\mathrm{CC}$.

\section{Clitic Climbing as an Emerging Isogloss in ArgSP}

In this section we present and discuss the results of diatopic variation in terms of CC within ArgSP.

In Table 6 , the results for $[+\mathrm{CC}]$ are listed according to variety and type of matrix verb for the 2011 data. All results are reported as a percentage of the total number of participants asked for each demographic and according to the highest degree of grammaticality: 


\begin{tabular}{|c|c|c|c|c|}
\hline \multirow{3}{*}{$\begin{array}{l}\text { Matrix Verb } \\
\text { Construction }\end{array}$} & ArgSp (all 2011 & River Plate & Cuyo & Central \\
\hline & Varieties & Varieties & Varieties & Varieties \\
\hline & Tested) $(\mathrm{N}=19)$ & $(\mathrm{N}=5)$ & $(\mathrm{N}=11)$ & $(\mathbf{N}=3)$ \\
\hline Ir+gerund & $89(\mathrm{~N}=17)$ & $100(\mathrm{~N}=5)$ & $82(\mathrm{~N}=9)$ & $100(\mathrm{~N}=3)$ \\
\hline Impersonal se $[+\mathrm{CC}]$ & $84(\mathrm{~N}=15)$ & $80(\mathrm{~N}=4)$ & $73(\mathrm{~N}=8)$ & $100(\mathrm{~N}=3)$ \\
\hline Impersonal se $[-\mathrm{CC}]$ & $67(\mathrm{~N}=12 / 18)$ & $40(\mathrm{~N}=2)$ & $90(\mathrm{~N}=9 / 10)$ & $33(\mathrm{~N}=1)$ \\
\hline Empezar a & $84(\mathrm{~N}=16)$ & $80(\mathrm{~N}=4)$ & $82(\mathrm{~N}=9)$ & $100(\mathrm{~N}=3)$ \\
\hline Estar+gerund & $79(\mathrm{~N}=15)$ & $80(\mathrm{~N}=4)$ & $73(\mathrm{~N}=8)$ & $100(\mathrm{~N}=3)$ \\
\hline Ir a & $74(\mathrm{~N}=14)$ & $100(\mathrm{~N}=5)$ & $64(\mathrm{~N}=7)$ & $67(\mathrm{~N}=2)$ \\
\hline Tener que & $74(\mathrm{~N}=14)$ & $60(\mathrm{~N}=3)$ & $82(\mathrm{~N}=9)$ & $67(\mathrm{~N}=2)$ \\
\hline Querer & $68(\mathrm{~N}=13)$ & $80(\mathrm{~N}=4)$ & $55(\mathrm{~N}=6)$ & $100(\mathrm{~N}=3)$ \\
\hline Deber & $67(\mathrm{~N}=12 / 18)$ & $60(\mathrm{~N}=3)$ & $80(\mathrm{~N}=8 / 10)$ & $33(\mathrm{~N}=1)$ \\
\hline Poder & $63(\mathrm{~N}=12)$ & $40(\mathrm{~N}=2)$ & $73(\mathrm{~N}=8)$ & $67(\mathrm{~N}=2)$ \\
\hline Comenzar a & $56(\mathrm{~N}=10 / 18)$ & $40(\mathrm{~N}=2)$ & $70(\mathrm{~N}=7 / 10)$ & $33(\mathrm{~N}=1)$ \\
\hline Necesitar & $53(\mathrm{~N}=10)$ & $40(\mathrm{~N}=2)$ & $45(\mathrm{~N}=5)$ & $100(\mathrm{~N}=3)$ \\
\hline Haber que & $26(\mathrm{~N}=5)$ & $40(\mathrm{~N}=2)$ & $18(\mathrm{~N}=2)$ & $33(\mathrm{~N}=1)$ \\
\hline Overall: & $68(\mathrm{~N}=153)$ & $65(\mathrm{~N}=42)$ & $68(\mathrm{~N}=95)$ & $72(\mathrm{~N}=28)$ \\
\hline
\end{tabular}

Table 6. Percentage of $[+\mathrm{CC}]$ acceptability to first degree of grammaticality in 2011 data by matrix verb and ArgSP variety

Under the same format, Table 7 below displays the results obtained for regions from the 2013 investigations. 


\begin{tabular}{|c|c|c|c|c|c|}
\hline & & & & & \\
\hline Matrix Verb & ArgSp & Buenos & Coastal & Lake & Southern \\
\hline Construction & (all 2013 & Aires & Patagonia & District & Patagonia \\
\hline & Varieties & $(N=8 \times 4)$ & $(N=3 \times 4)$ & $(N=7 \times 4)$ & $(N=6 \times 4)$ \\
\hline & Tested) & & & & \\
\hline & $(\mathrm{N}=24 \times 4)^{10}$ & & & & \\
\hline Comenzar a & $84(\mathrm{~N}=81)$ & $75(\mathrm{~N}=24)$ & $75(\mathrm{~N}=9)$ & $92(\mathrm{~N}=26)$ & $92(\mathrm{~N}=22)$ \\
\hline Empezar a & $74(\mathrm{~N}=71)$ & $44(\mathrm{~N}=14)$ & $84(\mathrm{~N}=10)$ & $92(\mathrm{~N}=26)$ & $88(\mathrm{~N}=21)$ \\
\hline Ir $a$ & $84(\mathrm{~N}=81)$ & $75(\mathrm{~N}=24)$ & $75(\mathrm{~N}=9)$ & $92(\mathrm{~N}=26)$ & $92(\mathrm{~N}=22)$ \\
\hline Continuar+gerund & $78(\mathrm{~N}=75)$ & $72(\mathrm{~N}=23)$ & $75(\mathrm{~N}=9)$ & $79(\mathrm{~N}=22)$ & $88(\mathrm{~N}=21)$ \\
\hline Ir+gerund & $72(\mathrm{~N}=69)$ & $54(\mathrm{~N}=17)$ & $67(\mathrm{~N}=8)$ & $96(\mathrm{~N}=27)$ & $71(\mathrm{~N}=17)$ \\
\hline Estar+gerund & $84(\mathrm{~N}=81)$ & $72(\mathrm{~N}=23)$ & $67(\mathrm{~N}=8)$ & $96(\mathrm{~N}=27)$ & $96(\mathrm{~N}=23)$ \\
\hline Seguir+gerund & $79(\mathrm{~N}=76)$ & $75(\mathrm{~N}=24)$ & $75(\mathrm{~N}=9)$ & $88(\mathrm{~N}=25)$ & $75(\mathrm{~N}=18)$ \\
\hline & 79 & 67 & 74 & 91 & 86 \\
\hline & $(\mathrm{N}=534 / 672)$ & $(\mathrm{N}=149)$ & $(\mathrm{N}=62)$ & $(\mathrm{N}=179 / 196)$ & $(\mathrm{N}=144)$ \\
\hline
\end{tabular}

Table 7. Percentage of $[+\mathrm{CC}]$ acceptability to first degree of grammaticality in 2013 data by matrix verb and ArgSp variety

Combining the overall results for CC acceptability in 2011 and 2013 and representing this pictorially on a map of Argentina reveals a surprising trend. Consider Figure 3: 


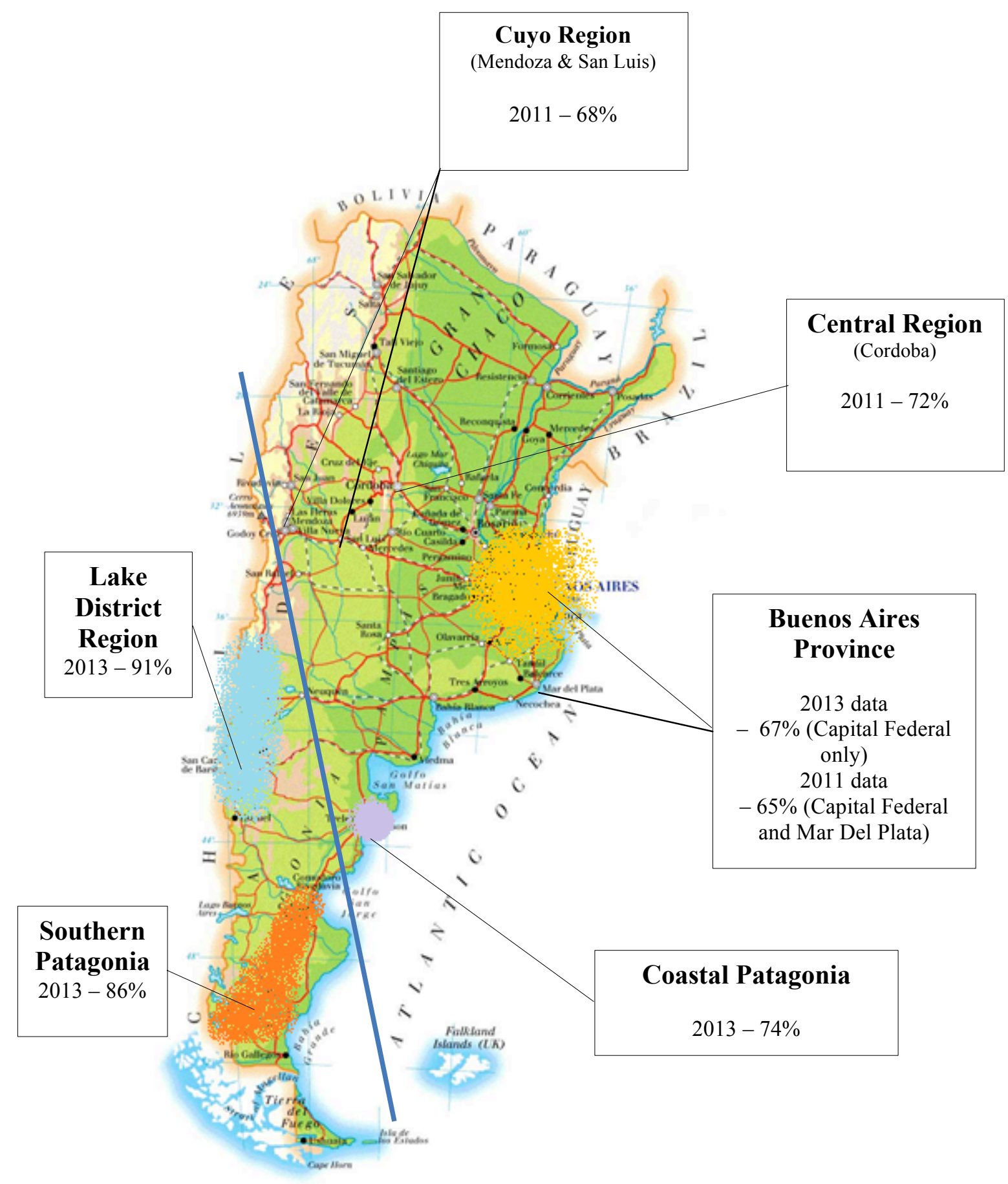

Figure 3. Map of CC acceptability rates from Whimpanny (2012) 2011 data and Ayres (2014) 2013 data, illustrating an isogloss across Argentina splitting higher-CC South Western and lower-CC North Eastern regions

A clear isogloss can be drawn across the country, separating those regions with higher $\mathrm{CC}$ acceptability rates (Lake District and Southern Patagonian varieties) from those with lower acceptance (River Plate/Buenos Aires, Central, Cuyo and Coastal Patagonia). The geographical pattern shown here is the first 
attempt to fully map out the distributions for CC acceptability in ArgSp based on empirical study.

In explaining the diatopic patterns of $\mathrm{CC}$ acceptability examined so far, comment must first be made on the apparent coastal/inland split, which is shown in Figure 3. The fact that the present study finds such a difference between the Coastal Patagonian varieties and the Southern Patagonian and the Lake District varieties may seem initially jarring, especially when one considers the fact that at a distance of $549 \mathrm{~km}$ from San Carlos de Bariloche, Puerto Madryn is much closer to the Lake District than Buenos Aires city, at $1077 \mathrm{~km}$ away. Similar distributions, however, can be seen in other Latin American Spanish (LAS, herein) varieties (e.g. see Canfield 1981: 28 \& 36 for Colombia and Bolivia); indeed, Lipski (1994: 8) claims that "Coastal speech differs markedly from highland dialects of the same countries, sometimes within a span of 100 miles". Furthermore, Canfield's (1962, quoted in Pottier (1992: 6)) assertion that "las regiones altas representan generalmente los principios del andalucismo, y las costas en pleno desarrollo" fully conforms with the present study's finding that the inland varieties are more conservative ${ }^{11}$ which is seen in the Lake District and Southern Patagonian varieties. Reasons for this dichotomy are essentially twofold; following Lipski (1994: 9) ports not only maintain strong links to patrimonial governments (and, by proxy, heightened standardising linguistic pressure), but furthermore are sources of "renewable linguistic input", given that port cities are primarily destinations of international trade and immigration. In the case of Puerto Madryn, the main city from whence the Coastal Patagonian data was collected in the present study, it is unclear whether the impact of a Welsh adstrate (Coupland \& Garrett 2010) will also have had a direct effect of CC acceptability in the Coastal Patagonian Region, but its status as a port will certainly have provided a considerable amount of variation in Spanish input in later decades, which may in turn push speakers towards linguistic accommodation and dialect levelling (see Trudgill 2004) resulting in a closer approximation to the standard, and thus a lower acceptability of CC. Furthermore, Virkel (2000: 172) explains that within urban centres in the Chubut province, such as Puerto Madryn and Trelew, a variety of ArgSp that is generally based on the Buenos Aires standard is widely the main variety in use. The area attracted much immigration, which helped cause the population to grow from 80 to 8500 between 1890 and 1955 (Virkel 2000: 122), due to booming industry. She reports that in Trelew there is a strong levelling mechanism in place due to historical influence (Virkel, 2000: 167-168), the media, a relatively long-standing education system (Virkel, 2000: 122) and relatively fluid communications links between the principal cities of Chubut and the capital (Virkel, 2000: 122, 126, 173).

However, the inland/coastal split cannot account for why Cuyo, albeit inland and therefore aligning with the rest of Western Argentinean varieties, behaves like a coastal variety instead. We would like to claim that the Cuyo data can be explained if we take into account the emerging urban nature of the capital cities in the Cuyo region which contrasts with the rather rural character of the

11 If we assert that andalucismo equates to conservatism, given the arguments that the main Spanish variety forming the basis of LAS in the colonial expansion was Andalusian (see Lipski 1994). 
majority of the rest of Argentina's provincial towns. On the topic of urban varieties, Mar-Molinero (1997: 54) notes that "those people who operate in contexts which bring them into complex social networks will be far more open to influences and pressures that might ultimately change their form of speaking" thus urban centres are more likely to promote linguistic norm which, in the present study, is [-CC] (which also affects Puerto Madryn and Trelew). She also draws the link between regional and social dialect variation, suggesting that it would be unwise to separate the two. Data from the Cuyo region, therefore, present an interesting discussion for the relationship between the inland/coastal split and the speech of urban varieties, given that data for this region was collected from the urban centres of San Luis and, the larger, Mendoza.

Furthermore, the reason why Cuyo speech most closely resembles the speech of the Buenos Aires/Mar del Plata region, contrasting with the high-CC acceptability in the more conservative Lake District and Southern Patagonian regions, could be the result of imposed socio-linguistic pressure of prestigious urban speech. In physical terms, the Cuyo region is much closer to the Rioplatense region than the Patagonian regions. Therefore, if Lipski's (1994) suggestion that the speech of Buenos Aires is gradually creeping "inroad" is correct, we should expect it to reach the Cuyo region first. As such, the isogloss shown in Figure 3 illustrates that diatopic variation of CC acceptability is not a simple case of inland/coastal split (or indeed even an East/West split), as the Cuyo data suggests that urban centres are more likely to accept more $\mathrm{CC}$ whatever their location. ${ }^{12}$

Additionally, western Argentinean territory, most notably the Cuyo region, was initially settled by Chile (Lipski, 1994), and therefore there may be the potential for reinforcement of low-CC levels via early contact with Chilean Spanish, given close geographical proximity, and ultimately producing a similar result to the one in Buenos Aires Spanish. In light of this question, a preliminary study of CC acceptability was carried out with 5 speakers in Santiago ${ }^{13}$ to attempt to offer some indication as to whether our ArgSp varieties (especially the Lake District, Southern Patagonian and Cuyo which were historically first settled by Chile) may have been involved in a substrate/adstrate situation with Chilean Spanish. Consider Table 8:

12 In order to take into consideration an accurate linguistic profile of the speakers, in addition to how urbanised their environment is, the speakers' age, gender and socio-economic status was analysed to give an indication of these variables' contribution - that is, choosing not to separate diastratic and diatopic tendencies in line with Mar-Molinero (1997: 53). Preliminary analyses of the data according to these socio-economic variables produced at times opposing results between 2011 and 2013 speaker gender, age and SES, and the work of Gudmestad (2005) and were therefore deemed inconclusive (see Ayres 2014 for a more complete social discussion of the 2013 data). Further research into how definitive the influence of these socio-economic factors are for $\mathrm{CC}$ would certainly be welcomed.

Speakers were all of high SES level, mainly between age 19-25 and some spoke other European languages (mainly English and some German). Only one of the five speakers had been born in Santiago. The methodology and questionnaire used was identical as in the 2013 Argentinean data collections. 
Variation and Optionality in Clitic Climbing in Argentinian Spanish Isogloss 2015, 1/2 275

\begin{tabular}{|c|c|c|c|c|c|c|c|c|c|c|c|}
\hline & $\begin{array}{l}\text { ArgSp } \\
(2011+ \\
2013) \\
\end{array}$ & $\begin{array}{l}\text { ArgSp } \\
(2011 \\
\text { only) } \\
\end{array}$ & $\begin{array}{l}\text { ArgSp } \\
(2013 \\
\text { only) } \\
\end{array}$ & $\begin{array}{l}\text { Chilean } \\
\text { Spanish }\end{array}$ & Cuyo & $\begin{array}{l}\text { Lake } \\
\text { District }\end{array}$ & $\begin{array}{l}\text { Southern } \\
\text { Patagonia }\end{array}$ & Central & $\begin{array}{l}\text { River } \\
\text { Plate }\end{array}$ & $\begin{array}{l}\text { Buenos } \\
\text { Aires }\end{array}$ & $\begin{array}{l}\text { Coastal } \\
\text { Patagonia }\end{array}$ \\
\hline $\begin{array}{l}\text { \%Overall } \\
{[+\mathrm{CC}]} \\
\text { acceptability }\end{array}$ & $\begin{array}{c}74 \\
(\mathrm{~N}=666)\end{array}$ & $\begin{array}{c}68 \\
(N=153)\end{array}$ & $\begin{array}{c}79 \\
(\mathrm{~N}=534)\end{array}$ & $\begin{array}{c}62 \\
(\mathrm{~N}=53)\end{array}$ & $\begin{array}{c}68 \\
(\mathrm{~N}=95)\end{array}$ & $\begin{array}{c}91 \\
(\mathrm{~N}=179)\end{array}$ & $\begin{array}{c}86 \\
(N=144)\end{array}$ & $\begin{array}{c}72 \\
(\mathrm{~N}=28)\end{array}$ & $\begin{array}{c}65 \\
(\mathrm{~N}=42)\end{array}$ & $\begin{array}{c}67 \\
(\mathrm{~N}=149)\end{array}$ & $\begin{array}{c}74 \\
(N=62)\end{array}$ \\
\hline
\end{tabular}

Table 8. Overall percentage of CC acceptability per variety including Chilean

$$
\text { Spanish }
$$

Table 8 suggests that, although Chilean Spanish does not converge with any specific western Argentinean variety, it shows a low acceptability percentage of $\mathrm{CC}$ in line with what we find in Buenos Aires, River Plate and Cuyo. In fact, communication links connecting Santiago de Chile and Buenos Aires, run through the Cuyo region, and, most usually, through both Mendoza and San Luis. It is therefore possible that Cuyo stands out from other western Argentinean varieties (Lake District and Southern Patagonia) because of strong communication links with both Buenos Aires and Chilean varieties, in combination with the urban features, which set it apart from the rural features of Southern Patagonia. We leave it to future work to engage in more rigorous investigations in those varieties.

Turning our attention now to the optionality of CC in the Central variety, the results obtained from this region present here comparable, if not only slightly elevated, overall $[+\mathrm{CC}]$ acceptability results against those reported from the Cuyo varieties. However, $\S 6$ will bring to light some rather unique tendencies in this variety, which potentially have a linguistic explanation. The tendency for cliticverb order in imperatives is observed, for example, 'nos juntemos', 'let's get together', instead of 'juntémonos' (or, heard more popularly in Argentina, 'juntemonós'). It is possible that the generalisation of anteposing clitics favours/conditions the acceptability for $[+C \mathrm{CC}]$. This is, perhaps, especially true of the matrix verbs that returned unexpectedly high percentages for $[+\mathrm{CC}]$ in the Central variety. It follows that if this more conservative [+CC] tendency is reinforced/coupled with another change, it is possible that these varieties will return higher percentages of $[+\mathrm{CC}]$ acceptability and eventually evolve into the type (b) CC languages described in the introduction of this paper, namely those with pervasive and obligatory CC, like Central Italian varieties and Sardinian, given adequate correlative forces driving this optionality.

Arguably one of the main contributions of the present study is the attention paid to, and the results gleaned from, Patagonian Spanish varieties, which clearly show high-CC acceptability compared to elsewhere in Argentina studied here. In the field of LAS dialectology, it seems that Patagonia eludes classification and description entirely; Henríquez Ureña's (1921) seminal work on LAS dialectology does not even mention Argentinean Patagonia -the only exception being a certain amount of linguistic attention regarding its native languages (see, for example, Fernández Garay 2013, inter alios). Therefore, it will not be surprising if future work shows that the explanation of the differences in CC acceptability are not based on socio-historical evidence alone, but rather that other grammatical properties, CC aside, distinguish Patagonian Spanish from other varieties of ArgSP. We suggest three possible historical explanations for this:

(i) either it is possible that the Lakes and Southern regions are in fact innovative, and independently expanding their overall acceptability of CC;

(ii) or, the converse may be true, in that the Lakes and Southern regions are conservative and maintain an earlier Argentinean grammar which other regions are moving away from; 
(iii) or, it is possible that Patagonian Spanish has always differed grammatically from other Argentinean varieties for two reasons: (a) it was the last region of Argentina to be settled and, thus, the Spanish input variety is likely to differ significantly from that of other parts of Argentina; and (b) it may have been subject to substrate influence from an indigenous language, such as Mapundungún, Tehuelche (among others), Welsh (which has its strongest presence in Coastal Patagonia), (Southern) Chilean Spanish, and/or the L2 Spanish of other European settlers.

Of these three explanations, the most likely scenario is a mix of (ii) conservatism and (iii) substrate influence - it is unlikely that Patagonian Spanish is innovative, given the trend for innovation in urban speech, and Lipski's (1994: 24) general observation that isolated speech communities are cited "as having retained earlier stages of a language which in larger communities has substantially evolved over the same time period". Unfortunately, poor documentation of settlement patterns means that the extent of substrate influence cannot be fully determined, although more study into this area could prove enlightening. Quoting Malvestitti (1993: 141) in Virkel (2000: 26), maybe the influence of a substrate language on the Spanish spoken in these areas does not have a deterministic influence, yet a reinforcing tendency on certain features. We leave research into the potential extent of influence of indigenous languages on Spanish in these areas to future research.

The findings here, however, certainly seem to reflect Davies' (1995) suggestion that CC has remained consistently prevalent in spoken Spanish since the 12th century, which is confirmed in a more recent study by Iglesias (2012). Both authors note, however, that $\mathrm{CC}$ declined in the written register from the 12th century and indeed is now dispreferred prescriptively both in written and spoken Peninsular Spanish (but see impersonal se, for example, (Gómez Torrego, 1999: 3332)). It is thus possible that the spoken 18th (and 19th) century Spanish, which served as input in the case of Patagonian varieties, already contained high-CC. This would be in line with the discussion of unusual grammatical features of Early Modern Spanish from the perspective of either Old or Modern Spanish which are usually under-discussed with regards to the evolution of Spanish (Octavio de Toledo y Huerta 2014). The Patagonian varieties tested in the present study, therefore, appear to demonstrate a continuation of the Medieval and Early Modern Spanish tendency for CC in the spoken register, whereas the speech of Buenos Aires displays more evidence of influence from the [-CC] speech of SPSp, which is understandable on the basis that it is a national capital and a large Atlantic port, of which both factors ensure strong links to the Peninsular standard.

\section{On Clitic Climbing "True” Optionality}

The $\mathrm{CC}$ isogloss separating high-CC and low-CC Argentinean varieties explains some of the variation attested on the basis of external triggers, but it does not resolve the issue of optionality within the same variety. It is precisely this issue that we focus on in this section and in particular we try to answer how/why certain verbs: (a) even in low-CC varieties, show a high-CC acceptability and vice versa; (b) interrupt the isogloss presented in Figure 3; (c) are compatible with/without 
$\mathrm{CC}$ within the same variety and across varieties; in other words we will focus on the 'true' optionality of CC when no other variable, internal or external, can be found to be at work.

First let us consider type (a) optionality, namely high CC acceptability for certain verbs in varieties that have generally lower acceptability rates, and vice versa. To this end, we turn to the following constructions: $i r+$ gerund (17), 'go'+gerund, and empezar a (18), 'start to', which show generally high levels of $\mathrm{CC}$ acceptance in all varieties except in Buenos Aires capital (2013 data):

a. María va aprendiéndolo

poco a poco mary go.3SG learn.GER-CL.DO.3SG.MAS little to little 'Mary is learning it little by little.'

b. María lo va aprendiendo poco a poco

(ArgSp/SPSp) mary CL.DO.3SG.MAS go.3SG learn.GER little to little (ArgSp:RP\&C(100\%)/LD(96\%)/SP(71\%)/Cu(82\%)/CP(67\%)/BsAs(54\%) )$/ \mathrm{SPSp})^{14}$

'Mary is learning it little by little.'

a. Juan empezó a prepararlo demasiado tarde john started.3SG to prepare.INFIN-CL.DO.3SG.MAS too late 'John started to make it too late.' (ArgSp/SPSp) b. Juan lo empezó a preparar demasiado tarde john CL.DO.3SG.MAS started.3SG to prepare.INFIN too late (ArgSp $(\mathrm{C}(100 \%) / \mathrm{LD}(92 \%) / \mathrm{SP}(88 \%) / \mathrm{CP}(84 \%) / \mathrm{Cu}(82 \%) / \mathrm{RP}(80 \%) / \mathrm{BsAs}($ 44\%))/SPSp)

'John started to make it too late.'

Results collected from all varieties for these configurations can be compared as shown in Table 9:

\begin{tabular}{|c|c|c|c|c|c|c|c|}
\hline & \multicolumn{5}{|c|}{ North of the isogloss } & \multicolumn{2}{|c|}{ South of the isogloss } \\
\hline & $\begin{array}{l}\text { River } \\
\text { Plate }\end{array}$ & Cuyo & Central & $\begin{array}{l}\text { Buenos } \\
\text { Aires }\end{array}$ & $\begin{array}{l}\text { Coastal } \\
\text { Patagonia }\end{array}$ & $\begin{array}{l}\text { Lake } \\
\text { District }\end{array}$ & $\begin{array}{l}\text { Southern } \\
\text { Patagonia }\end{array}$ \\
\hline Ir+gerund & $\begin{array}{l}100 \\
(\mathrm{~N}=5)\end{array}$ & $\begin{array}{l}82 \\
(\mathrm{~N}=9)\end{array}$ & $\begin{array}{l}100 \\
(\mathrm{~N}=3)\end{array}$ & $\begin{array}{l}54 \\
(\mathrm{~N}=71)\end{array}$ & $67(\mathrm{~N}=8)$ & $\begin{array}{l}96 \\
(\mathrm{~N}=27)\end{array}$ & $71(\mathrm{~N}=17)$ \\
\hline Empezar a & $\begin{array}{l}80 \\
(\mathrm{~N}=4)\end{array}$ & $\begin{array}{l}82 \\
(\mathrm{~N}=9)\end{array}$ & $\begin{array}{l}100 \\
(\mathrm{~N}=3)\end{array}$ & $\begin{array}{l}44 \\
(\mathrm{~N}=67)\end{array}$ & $84(\mathrm{~N}=8)$ & $\begin{array}{l}92 \\
(\mathrm{~N}=26)\end{array}$ & $88(\mathrm{~N}=21)$ \\
\hline
\end{tabular}

Table 9. Diatopic variation in percentage $\mathrm{CC}$ acceptability with $i r+$ gerund and empezar a constructions

Table 9 displays 100\% acceptability rates returned by River Plate and Central speakers and a high-CC rate recorded for the Cuyo data for $i r+$ gerund (17), 'go' +gerund, both of which are uncharacteristic for the northern side of the isogloss. Contrastingly, for the same matrix configuration, Southern Patagonia speakers present us with an unexpectedly low-CC acceptability rate. CC in constructions with embedded gerunds has been distinguished in the literature as

$14 \quad$ Where River Plate (RP); Cuyo (Cu); Central (C); Buenos Aires (BsAs); Coastal Patagonia (CP); Lake District (LD); and Southern Patagonia (SP). 
being more frequent than in those with embedded infinitives (Bybee 1985, Iglesias 2012, inter alios). Our data in Table 9 above show that embedded gerunds do not promote higher rates of CC categorically and indeed here we find a mix of unexpectedly high and low $\mathrm{CC}$ rates, which are uncharacteristic for the averages for their regions. Furthermore, Table 9 reveals that empezar a, 'start to', constructions in Buenos Aires produced a very low acceptability rate not only in comparison with data from the south of the isogloss, as would be expected, but also compared to all other data sets from the north.

Scrutinising our data further reveals additional distinctions (especially surrounding data from the Central variety) in the same vein as those presented in Table 9, which serves merely to provide an indication of this type (a) optionality. It is undeniable that on a verb-by-verb basis there are certain variety/matrix verb combinations that buck the trends otherwise mapped out by the isogloss of $\S 5$, which signals the lack of a hard-and-fast rule for $\mathrm{CC}$ with each verb and variety combination. In other words there is a clear amount of optionality for clitic placement in this respect.

Now, let us turn our attention to type (b) optionality: data which reveal cuts across the isogloss presented in $\S 5$. In sharing a common geographic centre, the River Plate data and the Buenos Aires data returned comparable percentages of average $[+\mathrm{CC}]$ acceptability, at $65 \%$ and $67 \%$ respectively. However, we report below some disparity between these two data sets when the findings are presented on a verb-by-verb basis. Consider Table 10:

\begin{tabular}{|c|c|c|c|}
\hline $\begin{array}{l}\text { Matrix } \\
\text { Construction }\end{array}$ & Verb & $\begin{array}{l}\text { River Plate Varieties } \\
(\mathrm{N}=5)\end{array}$ & Buenos Aires $(N=8 \times 4)$ \\
\hline Ir+gerund & & $100(\mathrm{~N}=5)$ & $54(\mathrm{~N}=17)$ \\
\hline Empezar a & & $80(\mathrm{~N}=4)$ & $44(\mathrm{~N}=14)$ \\
\hline Estar+gerund & & $80(\mathrm{~N}=4)$ & $72(\mathrm{~N}=23)$ \\
\hline Ir $a$ & & $100(\mathrm{~N}=5)$ & $75(\mathrm{~N}=24)$ \\
\hline Comenzar a & & $40(\mathrm{~N}=2)$ & $75(\mathrm{~N}=24)$ \\
\hline Overall: & & $65(\mathrm{~N}=42)$ & $67(\mathrm{~N}=149)$ \\
\hline
\end{tabular}

Table 10. Comparison of River Plate and Buenos Aires data

From Table 10, only data for estar+gerund, 'be'+gerund, produced comparable results from Buenos Aires and River Plate; all other verbs returned divergent findings. Acceptance rates for the River Plate data are more or less double those of the Buenos Aires speakers for CC with ir+gerund, 'go'+gerund, empezar a and comenzar a, both 'start to', despite both data collections coinciding on performing interviews with speakers from Buenos Aires (capital). It could be postulated that such differences may be a reflection of too small a sample size or could be due to differences in the linguistic profiles of the selected speakers. Even when taking these factors into consideration, the results still serve to highlight the optionality of $\mathrm{CC}$ with these verbs as a strong feature of the phenomenon; no hard and fast rule, internal or otherwise, governs clitic placement even for speakers of the same variety.

Finally, the third type of optionality that we consider is (c) how and why certain verbs are compatible with/without CC. For certain verbs, CC is prescriptively more constrained than with others. For instance, it is not clear how and why haber que (19), 'have to'/'must', and necesitar (20), 'need to', can 
accept CC, and also how and why the impersonal se clitic (21) can be accepted in its lower position.

a. Hay que comerlo

there-is.3SG that eat.INFIN-CL.DO.MAS.3SG

antes de la fecha de vencimiento

(SPSp/ArgSp)

before of the date of expiry

'One has to eat it before the expiry date.'

b. Lo hay que comer antes de la fecha de

CL.DO.MAS.3SG there-is.3SG that eat.INFIN before of the date of vencimiento

(*SPSp/?ArgSp(26\%))

expiry

'One has to eat it before the expiry date.'

(20)

a. Seguramente, necesitarán lavarse los surely need.FUT.3PL wash.INFIN-CL.PASS.3PL the dientes

(ArgSp/SPSp)

teeth

'They are sure to need their teeth cleaning'

b. Seguramente, se necesitarán lavar los

surely CL.PASS.3PL need.FUT.3PL wash.INFIN the

dientes $\quad($ ArgSp:C(100\%)/?RP(40\%)/?Cu(45\%))/*SPSp)

teeth

'They are sure to need their teeth cleaning'

(21) a. Puede jugarse al fútbol en cualquier can.3SG play-INFIN-CL.IMPERS.3SG to-the football in any pueblo de la Argentina (ArgSp:Cu(90\%)/RP(40\%)/C(33\%))/*SPSp) town of the argentina

'You can play football in any town in Argentina'

b. Se puede jugar al fútbol en cualquier

CL.IMPERS.3SG can.3SG play.INFIN at-the football in any

pueblo de la Argentina

town of the argentina

'You can play football in any town in Argentina'

Importantly, what our data reveals is that optionality is intrinsic to CC even in these constructions which are prescriptively banned from exhibiting it. Consider Table 11:

Haber que

\begin{tabular}{lll} 
River Plate & Cuyo & Central \\
\hline$+\mathbf{C C}$ & $+\mathbf{C C}$ & $+\mathbf{C C}$ \\
\hline $\mathbf{4 0}(\mathrm{N}=2)$ & $18(\mathrm{~N}=2)$ & $33(\mathrm{~N}=1)$ \\
$40(\mathrm{~N}=2)$ & $45(\mathrm{~N}=5)$ & $\mathbf{1 0 0}(\mathrm{N}=3)$
\end{tabular}

Table 11. Acceptability of CC with constructions for which $\mathrm{CC}$ is constrained prescriptively (haber que and necesitar) 
CC with haber que (19), 'have to'/'must', and necesitar (20), 'need to', which prescriptively disallow [+CC] (see Butt \& Benjamin, 2004: 146 for CC with haber que and Gómez Torrego, 1999: 3336 for CC with necesitar) did return some significant $[+\mathrm{CC}]$ results. Equally, $[-\mathrm{CC}]$ in impersonal se constructions, such as (21), which disallow [-CC] prescriptively (Gómez Torrego, 1999: 3336), was reported in our studies here. Consider Table 12:

\begin{tabular}{llll} 
& River Plate & Cuyo & Central \\
\cline { 2 - 4 } Impersonal & $-\mathrm{CC}$ & $-\mathrm{CC}$ & $-\mathrm{CC}$ \\
\cline { 2 - 4 } se & 40 & $\mathbf{9 0}$ & 33 \\
& $(\mathrm{~N}=2)$ & $(\mathrm{N}=9 / 10)$ & $(\mathrm{N}=1)$
\end{tabular}

Table12. Acceptability of $\mathrm{CC}$ with constructions for which $[-\mathrm{CC}]$ is constrained prescriptively (impersonal se)

Most striking results from Tables 11 and 12 include: (i) a 100\% acceptability rate for CC with necesitar, 'need to', in Central varieties, contra SPSp (and contra the general trend for lower-CC acceptability on the northern side of the isogloss); (ii) Cuyo produced significant deviations from the standard for enclitic impersonal se pronouns (see Table 12) and also proclitic object pronouns with haber que, 'have to'/'must', (see Table 11); and (iii) a relatively high-CC acceptability rate for the [+CC] haber que, 'have to'/'must', (see Table $11)$, in the River Plate data was produced. When comparing this with the standard (for which we would expect a $0 \%[+\mathrm{CC}]$ acceptability), and considering that the River Plate results were more than double the Cuyo results $(18 \%)$, the natural question is: what can cause such a divergence? From the variables that we discussed, not a single one clearly stands out as the one driving such deviations. In what follows, we examine (a) how the correlation between restructuring and $\mathrm{CC}$, although fundamentally correct, cannot capture and/or predict all attested optionality; and (b) how we can conceptualise such optionality.

In the literature it is claimed that $\mathrm{CC}$ is intrinsically linked to restructuring. According to this approach (Bok-Bennema \& Kampers-Manhe 1994; Kayne 1989, 1991, 1994; Roberts 1991, 1994, 1997, inter alios), CC is usually correlated with monoclausality, that is, the clitic pronoun is generated in the embedded clause and undergoes head-to-head movement to attach to the infinitive verb with which it forms a unit (Gonzalez Lopez 2008: 154). Assuming this to be so, then the prediction is that the spread of CC, which we have witnessed in some varieties of ArgSp, should essentially lead to a spread of restructuring contexts, which in turn permit CC. Moreover, the directionality should be from one restructuring class of verbs to the next, following a cline of monoclausality along the lines of Wurmbrand (2001) and Cinque (2002) - consider Table 13. More concretely, the prediction would be that optional control verbs such as querer, 'want', which seat low in a monoclausality hierarchy would not constitute one of the expansion environments for $\mathrm{CC}$ in $\mathrm{ArgSp}$ unless all preceding more monoclausal contexts also exhibit $\mathrm{CC}$. 


\section{Degree of}

Matrix Verb

$\underline{\operatorname{ArgSp}}(\mathrm{N}=1152011+2013 ;$

Monoclausality

$\left.\underline{\mathbf{N}}^{\mathbf{1 9}}\right)^{15}$

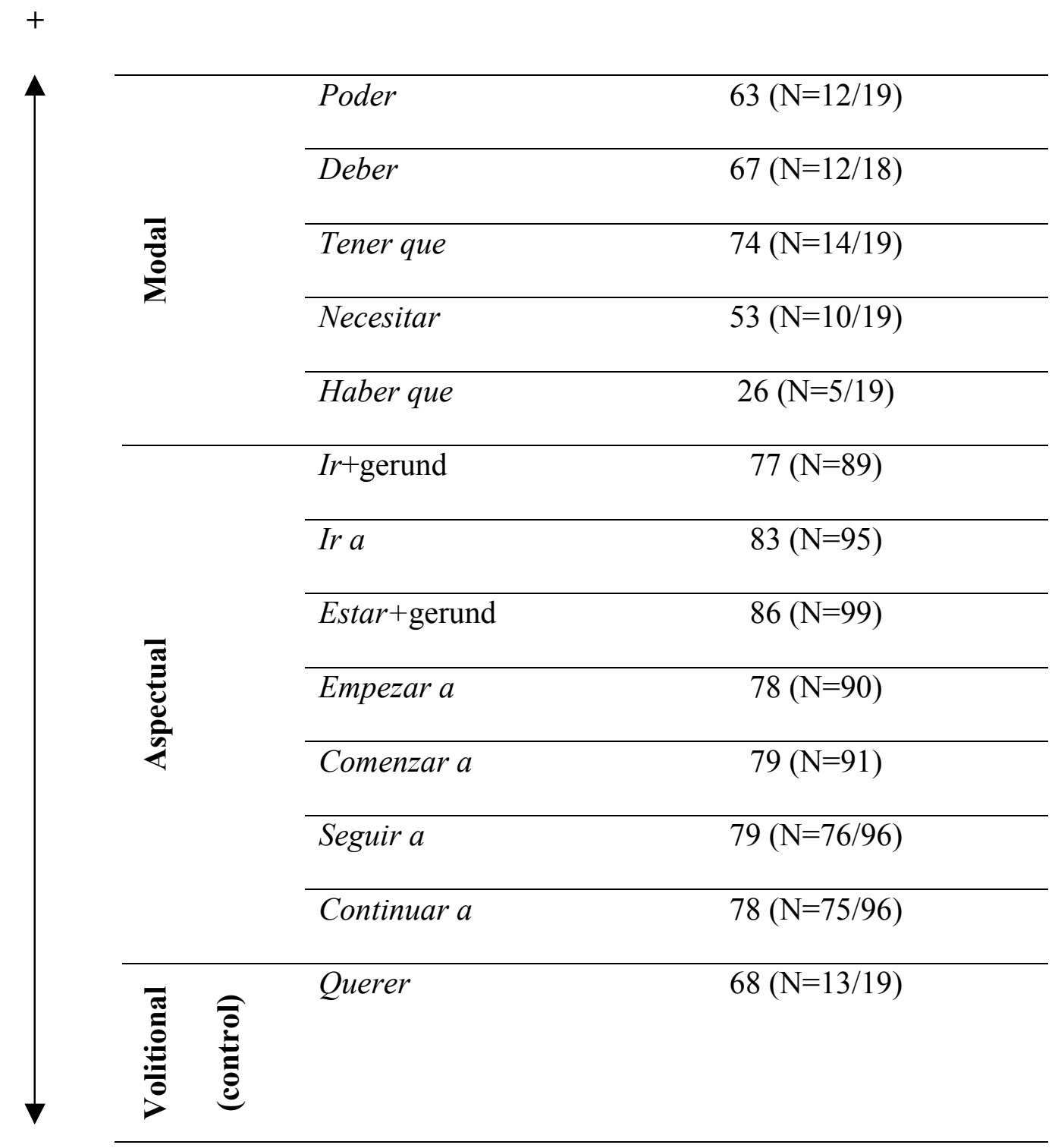

Table 13. Is expansion of $\mathrm{CC}$ in ArgSp according to restructuring?

However, as shown in Table 13, this prediction is only partially borne out for ArgSp since although $\mathrm{CC}$ with querer is not frequent, it is however still possible and, according to our data, is more accepted than CC with some modals.

15 Total number of tokens for 2011 and 2013 data is $115 ; 18 / 19$ total tokens were collected in 2011 data only; 96 total tokens were collected in 2013 data only. 
Moreover, we observe that more monoclausal domains, such as modals and aspectuals, do not show a uniform expansion with regard to CC. For instance, we cannot explain why necesitar behaves so differently from other modals, namely in admitting CC. Likewise, the restructuring hierarchy in Table 13 fails to explain why certain aspectuals admit more $\mathrm{CC}$, whereas modals on the whole do not seem to admit as much. All in all, although restructuring is definitely a necessary condition for $\mathrm{CC}$, we observe that $\mathrm{CC}$ does not equally spread along the cline of monoclausality and is instead far more patchy; in fact, "leap-frogging" (in the sense of Chambers \& Trudgill (1980)).

\section{Capturing the optionality of CC in the grammar of Spanish}

So far, we have established that the answer to the question 'Is CC a syntactic parameter or not?' is that the only necessary grammatical conditions for it to appear are (i) NSP on the null setting and (ii) a restructuring context. To capture this we first employ the model by Roberts (2012) and Biberauer \& Roberts (2012) on parametric hierarchies, according to which, we conclude that $\mathrm{CC}$ cannot be a macro- or meso-parameter. However, we note that this model cannot fully capture the type of variation we get in ArgSp because of cases of true optionality, as discussed in the previous section, where we witnessed different verbs of the same category behaving differently for the same speaker (and/or even the same verb on different occasions for the same speaker although we cannot show this here with the methodology used). Therefore, in order to explain this true optionality, we then employ Borer (2003), alongside Adger \& Smith (2007) and Adger (2013) for whom "the actual morphosyntactic properties of a particular language (especially the form and properties of morphemes) are a conventionalization of distributional occurrences, for which frequency may be an important factor ..." (Adger 2013: 2 ), thereby including these "distributional" tendencies as a crucial element to our explanation of the $\mathrm{CC}$ optionality.

First, according to Roberts (2012) and Biberauer \& Roberts (2012), parameters may be viewed as macro, meso, micro or nano, depending on the size of the class of elements whose behaviour they regulate. For them, macroparameters are all elements of a given type, meso-parameters are a featurally specifiable subset of the elements of a given type, micro-parameters are the smallest definable sub-class of elements of a given type, and nano-parameters are one or more individual lexical items - see also Roberts' (2012) and Biberauer \& Branigan's (2012) classification in (22):

(22) For a given value $\mathbf{v}_{\mathrm{i}}$ of a parametrically variant feature $\mathrm{F}$

a. Macroparameters: all heads of the relevant type share $\mathbf{v}_{\mathbf{i}}$

b. Mesoparameters: all functional heads of a given category (e.g. all verbal heads, all nominal heads, all $-\varphi$-bearing heads or all finite $\mathrm{Cs}$ ) share $\mathbf{v}_{\mathrm{i}}$;

c. Microparameters: a small subclass of functional heads (e.g. auxiliaries, pronouns) share $\mathbf{v}_{\mathrm{i}}$;

d. Nanoparameters: one or more idiosyncratic lexical items are specified for $\mathbf{v}_{\mathbf{i}}$. (Biberauer \& Roberts 2012: 268) 
If we adopt the parameter classification in (22) and we apply it to CC then we will end up with the following parametric classification of CC, as in Table 14:

\begin{tabular}{|c|c|c|}
\hline Type of parameter & Definition & Example \\
\hline nano-parameter & $\begin{array}{l}\text { different featural makeup of a } \\
\text { lexical head within the same } \\
\text { category, for instance, modals } \\
\text { or aspectuals or causatives }\end{array}$ & $\begin{array}{l}\text { poder behaving differently } \\
\text { from deber despite both } \\
\text { belonging to the modal } \\
\text { verbal category }\end{array}$ \\
\hline micro-parameter & $\begin{array}{l}\text { different featural makeup of } \\
\text { one category of restructuring } \\
\text { verbs vis-à-vis another } \\
\text { category of restructuring } \\
\text { verbs }\end{array}$ & $\begin{array}{l}\text { modals behaving differently } \\
\text { from aspectuals and/or } \\
\text { causatives }\end{array}$ \\
\hline meso-parameter & 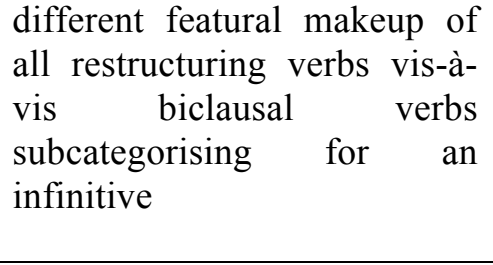 & $\begin{array}{lr}\text { restructuring } & \text { verbs } \\
\text { behaving differently from } \\
\text { perception or declarative } \\
\text { verbs which } \\
\text { subcategorise for an } \\
\text { infinitive }\end{array}$ \\
\hline macro-parameter & $\begin{array}{l}\text { different featural makeup of } \\
\text { all finite } \mathrm{v} \text { heads vis-à-vis } \\
\text { nonfinite } \mathrm{v} \text { heads }\end{array}$ & proclisis or enclisis \\
\hline
\end{tabular}

Table 14. Nano/micro/meso/macro-parametric analysis of CC in ArgSp

According to this refined parametrisation of $\mathrm{CC}$ in Table 14, we can now arrive at a better understanding of $\mathrm{CC}$ in ArgSp because we can now explain: (a) why out of the three restructuring contexts (modals, aspectuals, and volitionals (of the modal type)), only aspectuals accept $\mathrm{CC}$ to a higher degree in contrast to modals which do not tolerate $\mathrm{CC}$ as much. Crucially, on a previous understanding we would expect first the modals to show spread of CC before encountering it among the aspectuals; (b) why certain lexical heads would show a different CC acceptability vis-à-vis other members of the same group. For instance, estar+gerund, 'be'+gerund, within the aspectual class of restructuring verbs and deber, 'must', within the class of modal verbs will both favour $\mathrm{CC}$, but not all members of either class; (c) likewise, we can now also capture the different behaviour of a couple of lexical items, namely haber que, 'have to'/'must', and necesitar, 'need to', which, nevertheless, both belong to the same class. Therefore, the conclusion we reach for ArgSp is that the optionality does not affect any micro-/meso- or macro-parametric settings. Consider Figure 4: 


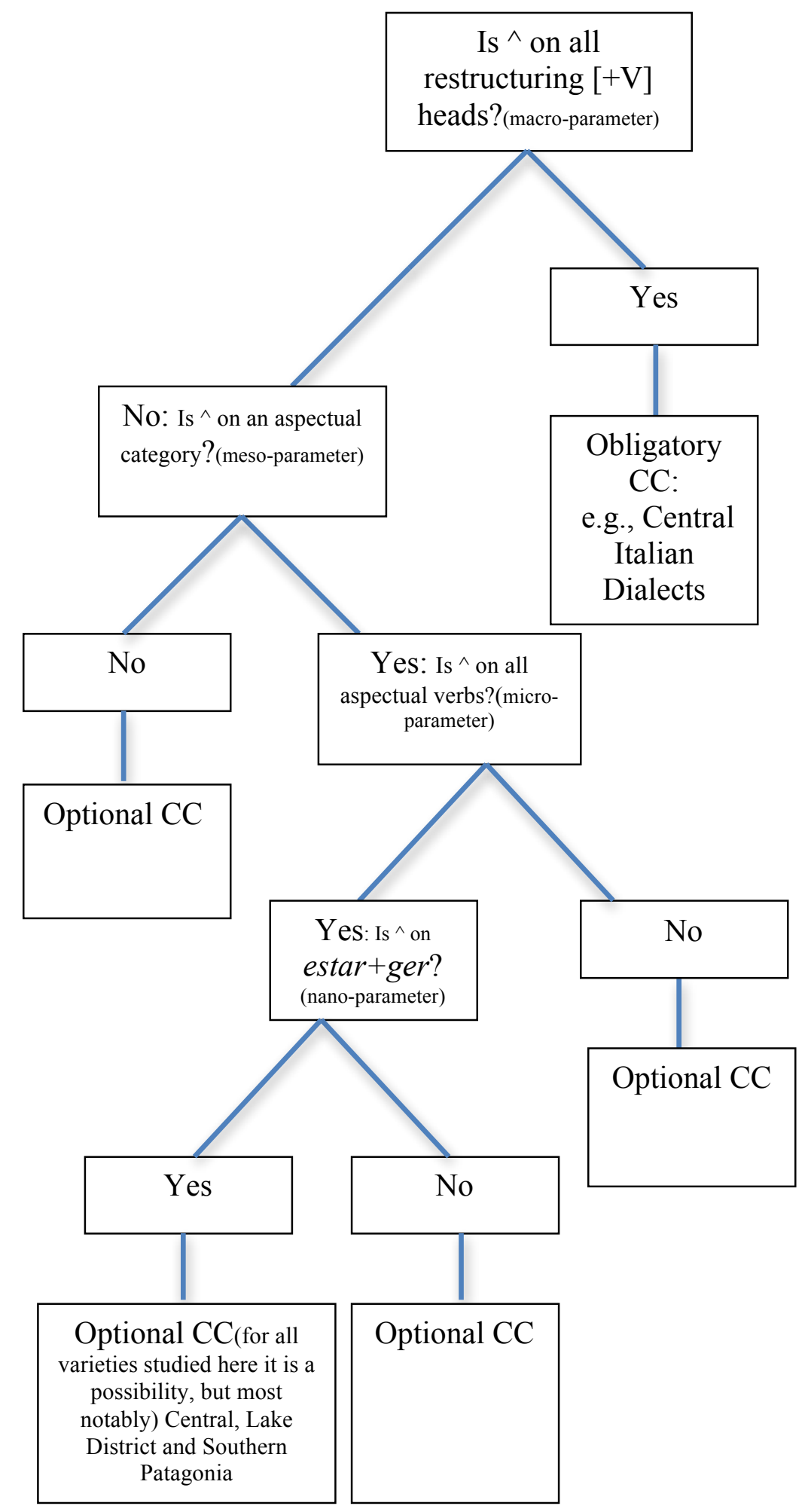

Figure 4. Nano/micro/meso/macro-variation and CC

However, although this refined parametrization captures well why certain grammatical properties, such as the NS, have to be met otherwise not allowing CC 
to obtain (macro-parameter), and also different lexical heads materialising different CC options, still it cannot fully capture the extent of optionality we found in our data. In other words, it cannot account for the optionality found when the same lexical item within a single variety shows both clitic placement possibilities. In fact, this sends us all the way back to the basics, namely to what nano-parameters seem to boil down to, that is the "Borer-Chomsky Conjecture" (as recently coined by Baker (2008)), namely variation is restricted to the properties and features of functional categories:

\section{(23) Borer-Chomsky Conjecture}

a. "Parametric variation is restricted to the lexicon, and insofar as syntactic computation is concerned, to a narrow category of morphological properties, primarily inflectional."

(Chomsky 2001: 2)

b. "The availability of variation [is restricted] to the possibilities which are offered by one single component: the inflectional component."

(Borer 1984: 3)

The reason why this is a more promising avenue is because aligning with (23) is compatible with Adger (2013: 2, 2015) and Adger \& Smith (2007), for whom frequency is (at the very least in part) responsible for conventionalising the distributional occurrences of the morphosyntactic properties of a particular language. At this stage we are in danger of circularity: - 'Why is there a high/low $+\mathrm{CC}$ rate in the grammar?' - 'Because the input data contains it'. Put differently, although frequency may explain how we get high/low/fluctuating $\mathrm{CC}$ rates in the grammar, it does not answer why CC should be so susceptible to such variation and optionality, and more generally, diachronic instability. Despite restructuring verbs triggering $\mathrm{CC}$ being functional categories, $\mathrm{CC}$ or not $\mathrm{CC}$ as such does not have any interpretive/semantic effect, contrary to the agreement phenomena studied by Adger (2013). Thus, it may well turn out to be that CC movement is an operation that occurs after the syntactic derivation (in the spirit of Embick \& Noyer 2001). In other words, the inherent variability in a single grammar is predicted from the feature-checking relationship: once checked, features are unavailable to the semantic interface, but are available to the phonological interface, that is, two options can have the same semantic interpretation but different pronunciations (Adger 2015:12) -this is precisely what we claim to be the nature of CC optionality.

This line of thought, essentially following Adger's (2013) proposal, can also explain some of the Labovian-type variation associated with $\mathrm{CC}$ since interaction of external factors with grammatical features can now be captured because the probability of a Labovian variant will determine whether a grammatical feature is present or not. Reinforcing tendencies -inline with the words of Malvestitti (1993: 141) quoted in Virkel (2000: 26)- will determine the frequency with which a variable surfaces. Moreover, it is unlikely to depend on just one of these tendencies, but rather the interaction of many. Essentially, this 
falls in line with Adger \& Smith's (2007) and Adger's (2013, 2015) proposals for the selection criteria of a variant from their Pool of Variants. For instance, in the case of Southern Patagonian, the Pool of Variants' structure included influence from: more $[+\mathrm{CC}]$ in the Spanish input of $18 / 19^{\text {th }} \mathrm{C}$; ; possible contact with all pervasive $[+\mathrm{CC}]$ of Italian immigrants; potential contact with SOV/OVS, agglutinative native languages (Fernández Garay, 2013: 62); and less contact with other varieties of Spanish -which were growing to allow [-CC] more so- because of the geographic isolation of Patagonia; all of which led to a higher probabilistic distribution of $[+\mathrm{CC}]$ in the input and which is taken on board by the child when configuring its grammar.

To conclude, we have seen that the availability of CC is gramatically constrained by the NSP and restructuring, but otherwise it is a post-syntactic operation which is amenable to great variation because it has no interpretive effect whatsoever. For this reason, it can be exploited/manipulated in a Labovian way because lexical items can be linked probabilistically to CC or its lack thereof.

\section{Conclusions}

In this paper, on the basis of novel data from ArgSp, we have shown that (i) no single internal variable seems to be the decisive trigger for $[+\mathrm{CC}]$, including the degree of restructurability of the matrix verb; (ii) there is an isogloss separating high-CC ArgSp varieties (such as Lake District and Southern Patagonia varieties) and ArgSp varieties that accept CC to a significantly lesser extent (such as Buenos Aires/River Plate, Cuyo and Central varieties); (iii) true optionality obtains despite diatopic variation since certain verbs (a) even in low-CC accepting varieties show a high-CC acceptability and vice versa; and (b) cut across the isogloss presented. It was claimed that optionality in $\mathrm{CC}$ in ArgSp is owing to nano-parametric variation, which is quite unstable diachronically. Crucially, the +/-CC do not yield interpretive/semantic effects and, therefore, the higher/lower rates of $\mathrm{CC}$ have been found not to be owing to a syntactic drive, but rather a lexical one. This contrasts with cases of macro-parametric change, such as that in Brazilian Portuguese vis-à-vis European Portuguese (see Cyrino 2010a, 2010b), which is syntactically driven. In future study, it would be interesting to explore the possible factors that affect the lexical variation at play in $\mathrm{CC}$, for example, by testing for possible contact influence, either from Italian or a native language, both in the varieties tested here and among other ArgSp ones, comparing results from linguistic empirical study with demographic information and existing sociolinguistic study.

\section{References}

Adger, David. 2013. "Variability and Grammatical Architecture". http://ling.auf.net/lingbuzz/002012 [Accessed http://dx.doi.org/10.1093/acprof:oso/9780198702894.003.0009

Adger, David. 2015. "Language Variability in Syntactic Theory". http://ling.auf.net/lingbuzz/002476 [Accessed 29/08/2015] 
Adger, David \& Jennifer Smith. 2007. "Variation in Agreement: a lexical featurebased approach".

http://ling.auf.net/lingbuzz/000774 [Accessed

$29 / 08 / 2015]$

http://dx.doi.org/10.1016/j.lingua.2008.05.007

Aissen, Judith L. \& David M. Perlmutter. 1983. "Clause Reduction in Spanish". In D. M. Perlmutter (ed.), Studies in Relational Grammar I, 360-403. London: University of Chicago Press. http://dx.doi.org/10.3765/bls.v2i0.2283

Ayres, Laura. 2014. Clitic Climbing in Argentinian Spanish. Unpublished undergraduate dissertation, University of Cambridge, U.K.

Baker, Mark. 2008. The Syntax of Agreement and Concord. CUP. http://dx.doi.org/10.1017/cbo9780511619830

Beukema, Frits \& Peter Coopmans. 1989. "A Government-Binding Perspective on the Imperative in English". Journal of Linguistics, Vol. 25, No. 2: 418-26. http://dx.doi.org/10.1017/s002222670001416x

Biberauer, Theresa \& Ian Roberts. 2012. "Towards a parameter hierarchy for auxiliaries: Diachronic considerations". Cambridge Occasional Papers in Linguistics Vol. 6, Article 9: 267-294.

Biberauer, Theresa \& Philip Branigan. 2012. "Microparametric expression of a macroparameter: Afrikaans verb clusters and Algonquian grammars". Unpublished ms: University of Cambridge and Memorial University, Newfoundland.

Bok-Bennema, Reineke \& Brigitte Kampers-Manhe. 1994. "Transparency Effects in the Romance Languages”. In M. L. Mazzola (ed.), Issues and Theory in Romance Linguistics, 199-217. Washington, D. C.: Georgetown University Press.

Borer, Hagit. 1984. Parametric Syntax: Case Studies in Semitic and Romance Languages. Dordrecht: Foris Publications. http://dx.doi.org/10.1017/s0022226700010963

Borer, Hagit. 2003. "Exo-skeletal vs. Endo-skeletal Explanations: Syntactic Projections and the Lexicon". In J. Moore and M. Polinsky (eds.), The Nature of Explanation in Linguistic Theory, 31-67. Chicago: Chicago University Press (distributed by CSLI).

Bosque, Ignacio et al. 2009. Nueva Gramática de la lengua española. Real Academia Española \& Asociación de Academias de la lengua española. Madrid: Espasa Libros.

Butt, John \& Carmen Benjamin. 2004. A New Reference Grammar of Modern Spanish. London: Hodder Arnold. http://dx.doi.org/10.1007/978-1-46158368-4

Bybee, Joan. 1985. Morphology. Amsterdam: John Benjamins. http://dx.doi.org/10.1075/tsl.9

Canfield, Delos L. 1962. La pronunciación del Español en América: Ensayo histórico-descriptivo. Bogotá: Instituto Caro y Cuervo. http://dx.doi.org/10.2307/337315

Canfield, Delos L. 1981. Spanish Pronunciation in the Americas. Chicago: University of Chicago Press. http://dx.doi.org/10.2307/341312

Cardinaletti, Anna \& Ur Shlonsky. 2004. "Clitic Positions and Restructuring in Italian". Linguistic Inquiry, Vol. 35, No. 4, Autumn 2004: 519-57. 
Cambridge, USA: The MIT http://dx.doi.org/10.1162/0024389042350523

Chambers, Jack \& Peter Trudgill. 1980. Dialectology. Cambridge: Cambridge University Press. http://dx.doi.org/10.1017/s0022226700013700

Chomsky, Noam. 2001. "Derivation by Phase". In M. Kenstowicz (ed.), Ken Hale: A Life in Language, 1-52. Cambridge, MA: MIT Press.

Cinque, Guglielmo. 1999. Adverbs and Functional Heads: A Crosslinguistic Perspective. New York \& Oxford: Oxford University Press. http://dx.doi.org/10.1017/s0022226705243396

Cinque, Guglielmo.2001. "'Restructuring' and the Order of Aspectual and Root Modal Heads". In G. Cinque \& G. Salvi (eds.), Current Studies in Italian Syntax; Essays offered to Lorenzo Renzi, 117-35. Oxford: Elsevier Science Ltd.

Cinque, Guglielmo. 2002. Functional structure in DP and IP. The Cartography of Syntactic Structures, Volume 1. New York: Oxford University Press.

Cinque, Guglielmo. 2006. "Restructuring and Functional Structure". Restructuring and Functional Heads, 11-34. New York: Oxford University Press.

Coupland, Nikolas \& Peter Garrett. 2010. "Linguistic landscapes, discursive frames and metacultural performance: the case of Welsh Patagonia". International Journal of the Sociology of Language, 205: 7-36. http://dx.doi.org/10.1515/ijs1.2010.037

Cyrino, Sonia. 2009. "The loss of clitic climbing in Brazilian Portuguese revisited". $\quad$ http://conf.ling.cornell.edu/DiGSX/abstracts/Cyrino.pdf [Accessed 29/08/2015]

Cyrino, Sonia. 2010a. "On romance syntactic complex predicates: why Brazilian Portuguese is different". Estudios da lingua(gem), Vitória da Conquista, Vol. 8, No. 1, June 2010: 188-217.

Cyrino, Sonia. 2010b. "On Complex Predicates in Brazilian Portuguese". IBERIA, Vol. 2, No. 2, 2010: 1-21.

Davies, Mark. 1995. "Analyzing Syntactic Variation with Computer Based Corpora: The Case of Modern Spanish Clitic Climbing". Hispania, Vol. 78, No. 2, May 1995: 370-377. http://dx.doi.org/10.2307/345438

Dikken, Marcel den \& Mariví Blasco. 2007. "Clitic Climbing in Spanish Imperatives". MS., The City University of New York. http://dx.doi.org/10.1075/la.103.05dik

Embick, David \& Rolf Noyer.2001. "Movement Operations after Syntax". Linguistic Inquiry, Vol. 32, No. 4, Fall 2001: 555-595. http://dx.doi.org/10.1162/002438901753373005

Emonds, Joseph. 1999. "How clitics license null phrases: A theory of the lexical interface". In H. C. van Riemsdijk (ed.), Clitics in the languages of Europe, 291-367. Berlin: Mouton de Gruyter. http://dx.doi.org/10.1515/9783110804010.291

Fernández Garay, Ana. 2013. "Complejidad sintáctica: las completivas del tehuelche”. In A. Fernández Garay, M. Censabella \& M. Malvestitti (eds.), Lingüística amerindia. Contribuciones y perspectivas, 59-71. Buenos Aires: Editorial de la Facultad de Filosofía y Letras, Universidad de Buenos Aires. 
Gómez Torrego, Leonardo. 1999. "Los verbos auxiliaries. Las perífrasis verbales de infinitivo". In I. Bosque. \& V. Demonte (eds.), Gramática descriptiva de la lengua española, Vol. II, 3323-3390. Madrid: Esposa Calpe.

González López, Verónica. 2008. Spanish Clitic Climbing. Ph.D.Dissertation, The Pennsylvania State University.

Gudmestad, Aarnes. 2005. "Clitic climbing in Caracas Spanish: A sociolinguistic study of ir and querer". Indiana University Linguistics Club Working Papers, Vol. 6: 1-14.

Henríquez Ureña, Pedro. 1921. "Observaciones sobre el español de América". Revista de Filología Española 8: 357-370.

Hualde, José Ignacio. 2005. "Variation in Spanish Pronunciation". The Sounds of Spanish, 18-40. Cambridge: CUP.

Iglesias, Olivier. 2012. Le placement des clitiques dans les complexes verbaux en espagnol: une nouvelle approche de la question. Unpublished Ph.D. thesis, University of Vincennes in Saint-Denis.

Kayne, Richard. 1989. "Null Subjects and Clitic Climbing”. In O. Jaeggli \& K. J. Safir (eds.), The Null Subject Parameter, 239-54. Dordrecht: Kluwer Academic Publishers. http://dx.doi.org/10.1007/978-94-009-2540-3_8

Kayne, Richard. 1991. "Romance Clitics, Verb Movement and Pro". Linguistics Inquiry, Vol. 22, No. 4, Autumn 1991: 647-63.

Kayne, Richard. 1994. The Antisymmetry of Syntax. Cambridge, MA: MIT Press.

Keniston, Hayward. 1937. The Syntax of Castilian Prose: The Sixteenth Century. Chicago: University of Chicago Press. http://dx.doi.org/10.2307/332696

Labov, William. 1972. Sociolinguistic Patterns. Philadelphia: University of Pennsylvania Press. http://dx.doi.org/10.1017/s0047404500004528

Leal de Andrade, Aroldo. 2010. "The Application of Clitic Climbing in European Portuguese and the Role of Register". In C. Borgonovo, M. EspañolEchevarría \& P. Prévost (eds.), Selected Proceedings of the $12^{\text {th }}$ Hispanic Linguistics Symposium, 97-108. Somerville, MA: Cascadilla Proceedings Project.

Lipski, John. 1994. Latin American Spanish. New York: Longman Group. http://dx.doi.org/10.2307/345539

Malvestitti, Marisa. 1993. "Castellano mapuchizado en la Línea Sur. Aproximaciones”. Actas. Primeras Jornadas de Etnolingüistica, Vol. 2: 137-144.

Mar-Molinero, Clare. 1997. The Spanish Speaking World. London: Routledge. http://dx.doi.org/10.2307/345669

Martineau, France. 1990. La Montée du clitique en moyen français: une étude de la syntaxe des constructions infinitives. Ph.D. Dissertation, University of Ottawa.

Monachesi, Paola. 1998. On certain properties of Romanian auxiliary (and modal) verbs, In G. Bouma, G. Kruijff \& R. Oehrle (eds.), Proceedings of the Joint Conference on Formal Grammar, Head-driven Phrase Structure Grammar and Categorial Grammar, 196-206. Saarbrücken.

Myhill, John. 1988. "The Grammaticalization of Auxiliaries: Spanish Clitic Climbing". Proceedings of the Fourteenth Annual Meeting of the Berkeley Linguistics Society: 352-363. http://dx.doi.org/10.3765/bls.v14i0.1792 
Myhill, John. 1989. "Variation in Spanish Clitic Climbing”. In T. J. Walsh (ed.), Synchronic and Diachronic Approaches to Linguistic Variation and Change (Georgetown University Round Table on Languages and Linguistics), 227-250. Washington, DC: Georgetown University Press. http://dx.doi.org/10.1017/s0022226700014900

Myhill, John. 1992. Typological Discourse Analysis, Quantitative Approaches to the Study of Linguistic Function. Oxford: Blackwell.

Napoli, Donna J. 1981. "Semantic Interpretation vs. Lexical Governance: Clitic Climbing in Italian”. Language, Vol. 57, No. 4, Dec. 1981: 841-87. http://dx.doi.org/10.2307/414244

Octavio de Toledo y Huerta, Álvaro S. 2014. "El cofre sin abrir de la memoria: aproximación a la (morfo)sintaxis del primer español moderno (ca. 16651825)". Talk at the University of Cambridge, 06/03/2014.

Picallo, Maria Carme. 1985. Opaque Domains. Ph.D. Dissertation, CUNY, New York.

Pottier, Bernard. 1992. "La variación lingüística y el español de américa”. Revista de Filología Española, Vol. LXXII, No. 3/4: 283-295. http://dx.doi.org/10.3989/rfe.1992.v72.i3/4.561

Ramsden, Herbert. 1963. Weak Pronoun Position in the Early Romance Languages. Manchester: Manchester University Press. http://dx.doi.org/10.2307/411581

Rivas, Alberto Mario. 1977. A theory of clitics. Ph.D. thesis, Massachusets Institute of Technology.

Rizzi, Luigi. 1976. "Ristrutturazione". Rivista di grammatica generativa 1: 1-54.

Rizzi, Luigi. 1978. "A Restructuring Rule in Italian Syntax". In Keyser (ed.), Recent Transformational Studies in European Languages, 113-158. Cambridge, MA: The MIT Press.

Rizzi, Luigi. 1982. Issues in Italian Syntax. Dordrecht: Foris Publications. http://dx.doi.org/10.1515/9783110883718

Roberts, Ian. 1991. "Excorporation and Minimality". Linguistic Enquiry 22: 209218.

Roberts, Ian. 1994. "Clitics, Case and Agreement in Welsh and Elsewhere". In I. Roberts (ed.), Research Papers in Welsh Syntax, Bangor Research Papers in Linguistics 5: 92-106.

Roberts, Ian. 1997. "Restructuring, Head Movement, and Locality". Linguistic Enquiry 28: 423-460.

Roberts, Ian. 2012. "On the nature of syntactic parameters: a programme for research". In C. Galves, S. Cyrino, R. Lopez \& J. Avelar (eds.), Parameter Theory and Linguistic Change, 319-334. Oxford: OUP.

Rochette, Anne. 1988. "Réseau de corrélations: sujet nul, montée et placement des clitiques et le caractère nominal des infinitives". Revue Québécoise de Linguistique Théorique et Appliquée Vol. 7, No. 3: 175-192.

Rodríguez Mondoñedo, Miguel, William Snyder \& Koji Sugisaki. 2004. "CliticClimbing in Child Spanish and the Theory of Parameters".MS., University of Connecticut and Mie University.

Rooryck, Johan. 2000. "Clitic Climbing". Configurations of sentential complementation: perspectives from Romance languages, 144-163. London: Routledge. http://dx.doi.org/10.4324/9780203187654 
Sinnott, Sarah \& Ella Smith. 2007. “SSubir o no subir? A look at clitic climbing in Spanish". MS., The Ohio State University and Pikeville College.

Trudgill, Peter. 2004. New-dialect formation: The inevitability of colonial Englishes. Edinburgh: Edinburgh University Press. http://dx.doi.org/10.1515/angl.2007.504

Virkel, Ana. 2000. El español hablado en Chubut: aportes para la definición de un perfil sociolingüístico. Ph.D. thesis, University of Valladolid.

Whimpanny, Helen. 2012. The null-subject parameter and clitic climbing in Argentinian Spanish. Unpublished undergraduate dissertation, University of Cambridge, U.K.

Wurmbrand, Susanne. 2001. Infinitives: Restructuring and clause structure. Berlin/New York: Mouton de Gruyter. http://dx.doi.org/10.1017/s1470542703260268

Wurmbrand, Susanne. 2003[2001]. Infinitives - Restructuring and Clause Structure. Berlin: Mouton de Gruyter. http://dx.doi.org/10.1515/9783110908329

Zagona, Karen. 1982. Government and Proper Government of Verbal Projections. Ph.D. Dissertation, University of Washington, Seattle, WA.

Zubizarreta, Maria Luisa. 1998. Prosody, Focus and Word Order: Linguistic Inquiry Monograph 33. Cambridge, MA: MIT Press. 